NBER WORKING PAPER SERIES

\title{
SALES FORCE AND COMPETITION IN FINANCIAL PRODUCT MARKETS: THE CASE OF MEXICO'S SOCIAL SECURITY PRIVATIZATION
}

\author{
Justine S. Hastings \\ Ali Hortaçsu \\ Chad Syverson \\ Working Paper 18881 \\ http://www.nber.org/papers/w18881 \\ NATIONAL BUREAU OF ECONOMIC RESEARCH \\ 1050 Massachusetts Avenue \\ Cambridge, MA 02138 \\ March 2013, Revised April 2017
}

We thank Steven Berry, Dennis Carlton, Judy Chevalier, J.P. Dube, Liran Einav, Matthew Gentzkow, Brigitte Madrian, Jesse Shapiro, Alan Sorenson, and participants at the QME conference, the NBER Household Finance, Public Economics and Industrial Organization conferences for helpful comments. Noele Aabye, Denrick Bayot, Sarah Johnston, Carolina Orellana, Adrian Rubli, Unika Shrestha and Jose Tudon provided outstanding research assistance. Hastings gratefully acknowledges financial support from the National Institute on Aging grant R01AG032411-01A2 and the U.S. Social Security Administration. Hortaçsu and Syverson thank the Chicago Initiative on Global Markets for financial support. We also thank the outstanding leadership and staff at CONSAR for making this project possible. The views expressed herein are those of the authors and do not necessarily reflect the views of the National Bureau of Economic Research.

At least one co-author has disclosed a financial relationship of potential relevance for this research. Further information is available online at http://www.nber.org/papers/w18881.ack

NBER working papers are circulated for discussion and comment purposes. They have not been peer-reviewed or been subject to the review by the NBER Board of Directors that accompanies official NBER publications.

(C) 2013 by Justine S. Hastings, Ali Hortaçsu, and Chad Syverson. All rights reserved. Short sections of text, not to exceed two paragraphs, may be quoted without explicit permission provided that full credit, including $\odot$ notice, is given to the source. 
Sales Force and Competition in Financial Product Markets: The Case Of Mexico's Social Security Privatization

Justine S. Hastings, Ali Hortaçsu, and Chad Syverson

NBER Working Paper No. 18881

March 2013, Revised April 2017

JEL No. D14,D18,G11,L20,L21,L51

\title{
ABSTRACT
}

This paper examines how sales force impact competition and equilibrium prices in the context of a privatized pension market. We use detailed administrative data on fund manager choices and worker characteristics at the inception of Mexico's privatized social security system, where fund managers had to set prices (management fees) at the national level, but could select sales force levels by local geographic areas. We develop and estimate a model of fund manager choice where sales force can increase or decrease customer price sensitivity. We find exposure to sales force lowered price sensitivity, leading to inelastic demand and high equilibrium fees. We simulate oftproposed policy solutions: a supply-side policy with a competitive government player and a demand-side policy which increases price elasticity. We find that demand-side policies are necessary to foster competition in social safety net markets with large segments of inelastic consumers.

Justine S. Hastings

Brown University

Department of Economics

64 Waterman Street

Providence, RI 02912

and NBER

justine_hastings@brown.edu
Chad Syverson

University of Chicago

Booth School of Business

5807 S. Woodlawn Ave.

Chicago, IL 60637

and NBER

chad.syverson@chicagobooth.edu

\author{
Ali Hortaçsu \\ Department of Economics \\ University of Chicago \\ 1126 East 59th Street \\ Chicago, IL 60637 \\ and NBER \\ hortacsu@uchicago.edu
}

A data appendix is available at http://www.nber.org/data-appendix/w18881 


\section{Introduction}

In 2015, 15 percent of the U.S. financial sector was employed in sales related occupations (850,000 employees out of 5.6 million, amounting to a wage bill of about \$56 billion). In 2011, the financial services industry spent approximately $\$ 10$ billion in advertising alone (Ad Age Data Center, 2012). These statistics contribute to rising policy concerns that marketing and advertising efforts by financial firms direct consumers to expensive products that are not otherwise differentiated from cheaper alternatives. This may lead to persistent price dispersion across observably similar products (credit cards, Ausubel 1991 and Ponce-Rodriguez 2008; mutual funds, Christoffersen and Musto 2002, Sirri and Tufano 1998, Hortaçsu and Syverson 2004, Choi et al. 2009, Egan 2015; mortgages, Hall and Woodward 2012 and Gurun et al. 2015; for a survey, see Hastings et al. 2013) Persistent price dispersion may be evidence of misguided financial decisions leading to, for example, lower savings for retirement or higher bankruptcy rates.

In response to such concerns, regulations and regulatory bodies monitoring sales and advertising strategies in these markets have grown. These changes include the inception of the Consumer Financial Protection Bureau in 2011 as a result of the Dodd-Frank Wall Street Reform and Consumer Protection Act as well as 2015 revisions to the Employee Retirement Income Security Act aimed at increasing the fiduciary responsibility of retirement fund brokers. Against this current, the industry maintains that advertising and sales-force-based marketing play a primarily informative role, increasing information and transparency and therefore competition.

In this paper, we bring new empirical evidence on how sales-force-based marketing, prices, and consumer choices interact to shape market outcomes in an imperfectly competitive financial product market. Specifically, we use unique administrative data from the privatization of social security in Mexico. The data contain detailed records for all individuals' fund manager choices, earnings, contributions, and residential location as well as data on fund manager fees and local sales force deployment. We develop an empirical model of the impact of sales force on fund manager choice. The model allows fund managers' sales forces to impact choices by increasing brand awareness and product salience in line with traditional informative advertising models (e.g., Butters (1977)), but it also allows sales force to impact price sensitivity as motivated by recent models of persuasive advertising and obfuscation (Gabaix and Laibson 2006; Carlin 2009; Ellison and Ellison 2009; Carlin and Manso 2011; Ellison and Wolitsky 2012; Grubb 2015a,b).

We estimate this model to understand firms' incentives to compete on price versus non-price attributes, to quantify the impact of sales force on observed market prices, and conduct simulations of oftsuggested market interventions to increase competition in privatized social safety net markets. While our study 
focuses on experiences and outcomes in one of the world's largest privatized social security markets, it may also suggest broader lessons as retirement savings and health insurance markets head towards greater individual control.

Mexico launched its fully privatized, defined contribution plan in 1997. Workers were able to choose among 17 regulator-approved social security account management firms well known through their pre-existing operations in consumer financial and insurance sectors. Tight regulations on investment portfolios resulted in a homogeneous-product, low-concentration market. Despite this, fees in the newly launched system were strikingly high. One year after the system's launch, with more than 90,000 Mexicans employed as sales agents promoting the funds (Figure 1), the average asset-weighted load was 23 percent: of every 100 pesos a Mexican worker contributed, only 77 were credited to his or her account. (In comparison, most U.S. mutual funds do not charge loads, and among the minority that do, maximum loads are around four percent.) In addition to loads, many fund managers charged an annual fee based on the balance in the worker's account. The assetweighted average annual fee across the 17 firms was approximately 0.63 percent. All told, between loads and annual fees, a 100-peso deposit by a typical Mexican worker into an account that earned a five percent annual real return would be worth only 95.4 pesos after 5 years. The fund managers receiving these funds had an average annual return on expenditures of 39 percent within five years of the launch of the system,.

To explain these outcomes, we develop a model of individual fund manager choice which allows price sensitivity and brand preferences (salience) to vary with exposure to a fund manager's sales force as well as with demographic characteristics. Two facts apparent in raw data on Mexican workers' fund manager choices motivate our model. First, investors were not price sensitive; they did not choose the fund with the mix of load and balance fees that minimized management costs given their contribution (load) and assets under management (annual fee) profile. Second, firms who invested heavily in sales force and advertising had both high prices and large market shares, suggesting that competition on advertising and non-price attributes substituted for competition on price. Our model allows for these patterns but does not impose them, letting us both quantify the effects of sales force on Mexican workers' choices and test between possible alternative theories driving the estimated effects.

Several features unique to our data and regulatory setting aid identification of demand parameters. First, we have location information for both sales agents and account holders which we use to measure sales force exposure. Second, the costs of choosing a given fund manager varied across investors (workers), even among those with similar location and demographic characteristics, giving us arguably exogenous variation in price. While fund managers had to set loads and annual fees (i.e., expense ratios) that applied to all workers, workers differed in their incoming account balances, the flow-versus-balance profiles of their contributions, as well as the fraction of the time they were in formal private sector employment and hence participating in the system (versus informal employment, government-sector employment, or unemployment). These differences 
caused the effective total cost of each fund manager to be worker-specific even though fee menus were set nationally. We use this variation in costs across program participants to identify price sensitivity, conditional on regional and demographic-level brand preferences.

We outline a model of supply of sales force to motivate instruments for marketing exposure. We develop three instruments. First, we use variation in sales force exposure across otherwise identical individuals due simply to the characteristics of nearby investors to identify the impact of sales force on individual-level demand (Waldfogel 2007). This advertising-spillovers instrumental variables approach exploits the fact that firms set sales force levels based on market-level aggregates while individuals choose fund managers based on their own preferences and characteristics. Second, we take advantage of baseline competitor brick-and-mortar bank branch presence. Controlling for a fund's own bank branch presence and brand-value, competing funds' bank branch presence affects the equilibrium deployment of sales agents in a given market. Third, we utilize the variation in the number of government sector employees and informally-employed workers across markets as a shifter of sales agent deployment. Since workers in these sectors did not participate in the privatized system, it may be more costly for sales agents to find potential pension account holders in the markets where a larger number of workers are employed outside of the formal private sector.

The estimates of our demand model suggest two channels through which exposure to fund managers' sales forces affect investors' choices. First, exposure to sales agents considerably decreased investors’ sensitivity to prices. Second, exposure to a particular manager's sales force also increased investors' perceptions of the non-price attributes of that manager and raised the probability of investors choosing it, increasing the market share of the fund (this second mechanism can be interpreted as lowering the "noise" or random utility component in the choice process). Therefore, agents both rotated and shifted out the (residual) demand curves for the fund managers they represented. These effects vary in magnitude across investors, with the largest effects observed for lower-income, male, and younger investors. The combination of these price sensitivity and non-price attribute preference effects imply that sales force exposure resulted in Mexican workers paying higher management fees and earning a lower return on their retirement investments. Our estimates imply that holding fees constant but eliminating the impact of sales force on preferences would lead to a 17 percent decrease in total fees paid in the system as investors sort to lower-fee firms.

We next develop a supply-side model of fund-manager pricing to explore key policy prescriptions and to quantify the impact that persuasive sales force had not just on choices, but on the high equilibrium fees observed in the market. We present three simulations. First, we measure the effect of eliminating the impact of sales force on preferences, allowing equilibrium fees to adjust. This quantifies the total (demand and supply) contribution to high equilibrium fees observed in the market. We find that fees would have been 62.1 percent lower, as more price-sensitive investors would cause fund managers to charge considerably lower fees in equilibrium. 
We then explore the impact of two specific policy interventions to increase price competition. First, we simulate the impact of introducing a government-backed competitor that charges a low fee (akin to a discount mutual fund in the U.S.). Forcing competition through a government-backed entity has been proposed as a way to increase competition in social safety net markets from health care to pensions. We find, somewhat surprisingly, that introducing a government competitor has little impact on average fees in isolation. Indeed, several firms best-respond by increasing fees and selling only to the very inelastic segment of the market. This provides empirical support to theoretical results that financial firms may choose to decrease price sensitivity of consumers in order to price high to a captive market (Carlin 2009, Carlin and Manso 2011; Sun 2014). It also echoes the "generic competition paradox" in the pharmaceutical industry, where generic entry can lead to higher brand-name prices (Frank and Salkever 1992, 1997; Berndt et al 2003; Davis et al. 2004). Since lowincome workers are more likely to be price-inelastic, the best-response fee increases impact this segment the most, suggesting that introducing a government competitor may be both ineffective and regressive.

Next, we examine the effects of increasing price sensitivity among the most price insensitive investors, for example, through financial literacy programs for low-education workers. In this counterfactual, we calibrate changes in price sensitivities among the least elastic customers to existing field- and naturalexperimental evidence on the impact of information campaigns targeting the financially illiterate (Hastings and Tejada-Ashton 2008; Duarte and Hastings 2012). We find such programs would result in 33.9 percent lower fees. Firms no longer respond by raising prices, as they no longer have a group of highly inelastic customers from whom to capture rents. Programs that increase price sensitivity among the most inelastic are important for incentivizing competition; all socioeconomic groups benefit from this policy when overall fees drop.

Finally, when we combine demand- and supply-side policies (the government competitor, pricesensitivity, and neutral advertising counterfactuals), our simulations show a 73.5 percent reduction in fees paid, as firms compete on price and a substantial fraction of workers choose the inexpensive government option. Thus the demand- and supply-side interventions are complementary.

While our counterfactual analyses are stylized and exclude unforeseen costs and consequences that actual interventions could introduce, we believe they are helpful in understanding the potential benefits and pitfalls of social safety net privatization, where product characteristics are complicated and the market covers a range of individuals with varying levels of education and abilities to solve complex problems.

This paper contributes to several literatures. First, we add to the literature modeling the impact of sales force on consumer decisions by extending current consideration set models to allow sales force to impact preferences for product characteristics such as price in addition to simply increasing the salience of the overall product. Many models of consideration (salience) are applied to every-day consumer products such as groceries or home electronics where prices and attributes are easy to see and experience (Mehta et al. 2003; van Nierop et al. 2010; Goeree 2008; Ching et al. 2009). The extension of this idea to financial product 
markets, where consumers may find it difficult to weigh or understand the various product characteristics when making choices, could be fruitful. Indeed, this notion has motivated recent models of strategic price obfuscation to explain outcomes in financial and retail markets (Gabaix and Laibson 2006; Carlin 2009; Ellison and Ellison 2009; Carlin and Manso 2011). We incorporate key aspects of these models into an estimable extension of a classic consideration set model. We take the model to the data to test if and how sales force impact price sensitivity in a major financial product market.

We also contribute to a growing stream of recent work looking at the influence of specific content and framing, often delivered by sellers' agents, on consumer decisions in financial markets. Ausubel (1999) and Ponce-Rodriguez (2008) use credit card industry-run field experiments to show that individuals are overly responsive to teaser rates, resulting in increased debt and interest payments. Cronqvist (2006) presents evidence that mutual fund flows respond positively to advertising expenditures. Choi et al. (2009) find high sensitivity of investment decisions to brand name in lab experiments, even among financially educated subjects. Bertrand et al. (2010) show borrowers are overly responsive to peripheral and emotional appeals in credit offers and insensitive to interest rates. Mullainathan et al. (2012b) use an audit study to show that U.S. mutual fund advisers reinforce biases of potential investors (rather than de-biasing them) and downplay the importance of management fees. Egan (2015) finds that brokers steer investors towards high-fee versions of otherwise identical funds. Gurun et al. (2015) show that direct mail advertising for sub-prime mortgages obfuscated fees and prices often by claiming low prices which were in fact not true. Hastings and TajedaAshton 2008, Hastings and Mitchell 2011, Duarte and Hastings 2012 demonstrate in field experiments within privatized social security markets that investors are sensitive to information framing and irrelevant information. Our framework not only lets us test for these effects directionally, but also quantifies them within an equilibrium framework and explores how they would shape prices, allocations and savings outcomes under proposed alternative policies.

Finally, we make a methodological contribution by being, to our knowledge, the first to address two non-standard behaviors in an estimable supply-side model.. These behaviors are empirically relevant in our setting and, we believe, other settings as well. One allows for firm best-response pricing functions where firms with market power may operate on inelastic portions of their demand curves, such as may be the case in the “generic competition paradox" or situations where firms face regulatory threat (Frank and Salkever 1992, 1997; Berndt et al. 2003; Davis et al. 2004). The other allows firms to differ in their planning horizons when they make their choices. As we show, these additional elements are consistent with basic patterns in the data and considerably improve the ability of the model to explain observed behavior in the market.

\section{Background}




\subsection{Brief History of Social Security Privatization in Mexico}

Mexico instituted its current privatized social security system on July 1, 1997. The system established individual ownership over retirement account contributions to replace the previous pay-as-you-go system. The government approved private investment managers, called Afores (Administradoras de Fondos para el Retiro), to manage the individual accounts. It established CONSAR (Comisión Nacional del Sistema de Ahorro para el Retiro [National Commission of the Retirement Savings System]) to oversee this new Sistema de Ahorro para el Retiro (SAR).

The privatization was done in two parts. In 1992, the government created private accounts for all pension holders in the system. From this point forward, social security contributions were placed into personal accounts rather than the general fund. The personal accounts were held by the Banco de México and earned a two percent real annual rate of return. However, the scope of privatization was largely limited to administrative tasks, such as record keeping and account statement generation, as all investment decisions were still made in a manner similar to the older system. Intending to improve efficiency in account management, the government fully privatized the system in 1997, moving official account management from Banco de México to the private Afores. Assets from the 1992 system could be transferred to individual accounts in Afores if bank receipts confirmed that there were deposits regarding pension funds in those accounts.

To be an Afore, a firm needed to meet minimum capital requirements, minimum ownership share by Mexican firms, and have experience in the financial sector in Mexico. Potential Afores submitted business plans, including fee schedules, to CONSAR for approval. Of the twenty-four firms that submitted applications and business plans, seventeen were approved to operate. Two of the rejected applicants entered the market several years later. ${ }^{1}$

The government took several steps to structure a competitive, low-cost market. The law stipulated that no Afore could have more than a 20 percent market share. The financial characteristics of Afores’ portfolios were strictly regulated; we detail this below. Afores had to submit any proposed fee changes for approval by CONSAR. To take advantage of scale economies, while ensuring against a natural monopoly in account management, a single, centralized processor (selected by CONSAR through a bidding process) handled database management and processed and recorded contributions, fees, and transactions. ${ }^{2}$

\footnotetext{
${ }^{1}$ The Online Appendix Section 5 describes the business plan submissions and the firms who submitted them in more detail (http://www.justinehastings.com/images/downloads/HHS_NBERWP_OnlineAppendix.pdf).

2 The fees paid by Afores for the centralized processor were as follows: registering a new account, 25.99 pesos; processing each contribution into the account, 0.62 pesos; switching an account's Afore, 5.47 pesos (charged to the Afore accepting the account). One dollar is approximately 12 Mexican pesos.
} 


\subsection{Fees and Investment Structure}

Mandatory contributions to a worker's retirement account come from two places: payroll taxes (from the worker and the employer) and government contributions. The worker automatically contributes a mandatory $1.125 \%$ of her base salary from her paycheck, the employer adds an additional 5.15\%, and the government contributes $0.225 \%$ so that each month, $6.5 \%$ of a worker's wages are contributed to the account. ${ }^{3}$ The worker chooses the Afore that manages the funds in her account. At the inception of the system, each Afore was required to offer one specialized investment fund, limited to holding Mexican government bonds and Mexican corporate bonds with at least AA- rating (corporate bonds were capped at 35\% of assets, including a 10\% cap on financial sector corporate bonds in particular). Thus, Afores' portfolios were primarily composed of Mexican government bonds. Tests for persistent outperformance using monthly returns show no significant difference between fund manager returns (Duarte and Hastings 2012).

Afores charged management fees on both automatic salary contributions (loads) and on assets under management (balance fees). Because the load fee was only charged on inflows from automatic salary deductions (there was no load fee for transferring funds from one Afore to another), it was referred to as "the flow fee.” This was quoted as a percent of the worker's salary instead of as a percent of the worker's contribution to the account. Hence a flow fee of $1 \%$ was actually a $15.4 \%$ load (1\% is $15.4 \%$ of $6.5 \%$ ). In 1997, flow fees ranged from $0 \%$ to $1.70 \%$ (i.e., $0 \%$ to $26.1 \%$ loads). In addition to the flow fee, firms charged balance fees ranging from $0 \%$ to $4.75 \%{ }^{4}$

The existence of these two separate fees implied that the relative cost ranking of Afores varied across individuals with their relative wage-to-balance ratio. This ratio depended on the worker's 1) wage rate, 2) balance at the system inception, and 3) probability of working in the formal private sector versus in the informal sector, public sector or not working. ${ }^{5}$ Because of inherent wage variation, differences in work histories, and even problems with accounting and management in the SAR 1992 system that created additional variation in the account balances at the inception of the system, workers' costs of using a particular Afore varied considerably even within relatively fine demographic cells. For example, for a worker who contributed consistently under the 1992 system and is currently and expects to remain employed in the public or informal

\footnotetext{
${ }^{3}$ As in the U.S there is an income cap above which there is no longer a social security tax. In addition to these contributions, the government added a "social contribution" of 5.5\% of the inflation-indexed Mexico City minimum wage that is available under certain conditions for unemployment insurance withdrawals, and the employer paid another $5 \%$ of the worker's base salary to a housing account for the worker.

${ }^{4}$ The Afore Inbursa started with only a fee as a percent of returns. We convert this to a balance fee on assets under management to facilitate comparison. Inbursa converted their return-based fee to a balance fee and later added a flow fee soon after the inception period and their acquisition of Capitaliza.

${ }^{5}$ Mexico has a strong informal sector, a large public sector with a separate pension system, and fluid movement of workers of all income and education levels among them. For example, approximately $30 \%$ of SAR account holders with a college education and $60 \%$ of workers with non-college backgrounds spent time in both the formal and informal employment sectors between 2005 and 2010.
} 
sector, the cheapest Afore would be one with a zero balance fee, regardless of how high its flow fee is. Conversely, for a worker who did not have a 1992 account but has high and steady contributions from current employment, the best Afore would be one with a low flow fee, even if it might have a high balance fee.

\subsection{Information, Financial Education, and Advertising Content}

To find the Afore with the lowest cost for them, workers had to perform a fairly complex calculation: gathering and digesting information on fees, projecting their future contributions, and incorporating their current SAR 1992 balance. This calculation could well have been cognitively burdensome; as of 2011, a household survey of account holders found that only approximately $40 \%$ of survey respondents were financially literate (able to answer basic questions about compounding, inflation and return risk) despite a college educated rate of 30\% (Hastings and Wilson 2017).

The government engaged in a broad informational campaign to explain to workers the system change and how and why to sign up with an Afore, but did not provide information on fees or financial literacy programs. We collected all television advertisements from the Nielsen-Ibope advertisement archive. ${ }^{6}$ According to this archive, CONSAR ran eleven unique advertisements about the new SAR system beginning in late 1996. The ads highlighted facts about the new system and how to choose an Afore but avoided mentioning specific Afore characteristics, fees, or investment profiles in an effort to remain impartial. Advertisements informed people that they had to sign up with an Afore, and strongly suggested that one would not have money for retirement if one failed to do so. They provided a phone number to call for information on registration. They emphasized the individual's ownership over their account and their right to choose any Afore. They recommended choosing the right Afore for you. "Right” was not defined, but implied match quality. For example, one ad presented choosing the right fitting glove as an analogy to choosing an Afore. (Examples of such ads include Nielsen-Ibope advertisement ID numbers 53655, 54846, 53460, 54738, 57229, 58039, 134003, 134087.)

Thus, to determine the best Afore, investors were substantially reliant on the Afores themselves for information on the specific choices. In part, this information was delivered through Afore ad campaigns on radio and television. However, the most intensive marketing mechanism used by the Afores were Agentes Promotores (henceforth referred to as “agents”). Agents were hugely important to the Afore choice process, in part because these agents were Afores' "faces on the ground” who were having the face-to-face conversations

\footnotetext{
${ }^{6}$ Nielsen Ibope is a Nielsen affiliate in Mexico that monitors and measures the advertising that consumers are exposed to, and the products that they buy. They have built a database of 35 years of television advertising in Mexico, which they make available to researchers for academic purposes through their website Publicity Tracks (Huellas de la Publicidad), at http://youspot.ibopeagb.com.mx/. (Date last accessed: June 8, 2015).
} 
with workers about their choices, and because once a worker decided on an Afore, they had to sign up with an agent representing that Afore.

While it is difficult to fully reconstruct a picture of sales tactics from the late 1990s, we researched and document three sources for descriptive evidence on advertising content and approach. First, we located and interviewed agents from the system startup period and obtained copies of one Afore's historical agent training materials. The training materials we reviewed were substantial but did not discuss fees or other financial fundamentals. Instead, they focused how agents could establish relationships and appeal to workers' personal fears or hopes. ${ }^{7}$ The training materials included a recommended reading list for being a successful sales agent. No books on financial investment or financial education appear on the list. Recommended titles include The Six-Hat Salesperson, Emotional Intelligence, and Selling the Invisible. Our interviewees recalled sales strategies that primarily appealed to company characteristics rather than financial fundamentals. For example, sales agents from Banamex and Bancomer would emphasize that their parent companies were the largest Mexican banks, while agents from Santander (a Spanish bank) would discuss its “international experience.” Both appeal to an intuitive or emotional representation of firm quality, echoing findings from Bertrand et al. (2010) and Mullainathan et al. (2012a). None of our interviewed agents reported ever explaining risk, diversification, how to understand or calculate price, or any other fundamentals. Moreover, they reported that sales agents were recruited for experience in sales, not for experience with financial products.

Second, we collected historic advertisements from Afores also using the Nielsen-Ibope advertisement video archive and print media from newspapers. The roughly $80 \%$ of ads by Afores focused on emotional appeals, with allusions to strength, experience, innovation and skill, as well associations with winning sports teams and celebrities. ${ }^{8}$ Among over 200 video advertisements run between 1997 and 1999, less than 20\% mentioned anything about costs or returns specifically. Among those that mentioned costs, the actual cost levels were typically unclear or irrelevant. For example, in one advertisement featuring apples, HSBC/Bancrecer/Dresdener stated that they do not "take a bite out of your savings apple” as other firms do, perhaps alluding to (but not stating explicitly) their zero flow fee. That firm, however, had by far the highest balance fee (4.75\%). Santander advertised that it was free to sign up your account with them, a statement that is true for all Afores. Banamex stated in one ad that they are the only Afore to offer a "near zero" fee at $0.20 \%$, which, given Banamex’s 26\% load, could only be correct under very particular and non-representative assumptions about incoming balances and contribution flows (which were not disclosed or explained). Of those mentioning returns, they would state facts about high returns in other investment markets the parent company owned - for example, savings funds in Chile. (Examples of the ads described in this paragraph include Nielsen-Ibope advertisement numbers 51666, 53332, and 52401.) In sum, the large majority of ads did

\footnotetext{
${ }^{7}$ An English translation of an example sales agent training handbook is in NBER Working Paper 18881, Online Appendix Section 4.

${ }^{8}$ Online Appendix Section 4, lists the advertisements with classification and content description.
} 
not mention fees or returns, and those that did were most likely to do so in a way that made comparing fees across firms difficult or made fees look low even though they were not. This complication of fee information is consistent with recent applied theory models of price obfuscation when at least some consumers are naïve or uninformed (Carlin 2009, Ellison and Ellison 2009).

Third, a 2010-2011 household survey of 7,500 account holders provides some additional support of consumer's lack of information. By this date, the government had undertaken several major reforms to the system accompanied by information campaigns to increase worker knowledge and fee sensitivity. However, survey results showed that the agents were still the most relied-on sources of information when selecting an Afore for workers from all education backgrounds (though those without a college degree were the least likely to rely on government-based information sources introduced in later years). ${ }^{9}$ While nearly $80 \%$ of individuals could correctly name the Afore who managed their account (survey responses were compared to administrative records), less than $10 \%$ of workers knew information about financial fundamentals like the fraction of their salary contributed to the account or their Afore's fees.

\subsection{Choosing and Changing Fund Managers}

When the new system officially began on July 1, 1997, workers could choose between any one of the seventeen approved Afores to manage their rolled over SAR 1992 account balances and their pension contributions going forward. Officially, if a worker did not choose any Afore after two years, their pension account was to be turned over to a consolidated account held by Banco de México for up to four years. If the worker still had not claimed their account at the end of the four year period, the account was to be assigned to an Afore by CONSAR. ${ }^{10}$ CONSAR's information campaign was effective in that almost all account value was claimed and reassigned to an Afore attached to a worker.

Workers had multiple channels through which to start their selection of an Afore. They could contact CONSAR, who would provide them with information on contacting Afores. They could alternatively contact Afores directly to seek information. Or, commonly, they could be approached directly by Afore sales agents on the street, at their home, or near their office. Based on our interviews with agents and sales force managers from the inception period, agents sought investors by canvassing malls, other public places, as well as offices and neighborhoods. Some set up stands in local public spaces, much like credit card solicitors do in the U.S. They did not have targeted names and addresses and characteristics of account holders (such private

\footnotetext{
${ }^{9}$ See Duarte and Hastings (2012) for a summary of later policy changes in the system and Hastings and Wilson (2017) for further survey results from the 2010-2011 Encuesta de Empleo, Ahorro y Retiro (EERA).

${ }^{10}$ The allocation process took place on January 1, 2001. Subsequent allocations took place every two months. The assignment rules change periodically, but the unclaimed accounts never sum to a large enough amount of money to be effective in generating price competition. In fact, in 2006, the sum total of the value in all unclaimed accounts was less than $5 \%$ of assets under management (Duarte and Hastings 2012).
} 
information would have been illegal to possess). They instead had to search for account holders in publically accessible areas and solicit their business. Such practices motivate our advertising spillovers instrument, explained in further detail in Section 4: conditional on own characteristics, an individual living near others who are attractive clients for a particular Afore will have a higher exposure to sales force, all else equal.

Overall, most Afores gained some market share in every municipality. Using our data on affiliates in the system during the inception period, the number of Afores with affiliates in a given county ranged from nine to seventeen, with a twenty-fifth percentile of fifteen, and a median of seventeen. Once a worker registered with an Afore, it was difficult to switch. Although workers were technically allowed to switch fund managers at their discretion, the right to switch the account and all of the paperwork resided with the Afore they currently belonged to, not the one they wanted to switch to. Thus, switching Afores was a long and difficult process until reforms in the early 2000s, and the fraction of workers who switched Afores between the system's inception in 1997 and 2005 was close to zero.

Given the difficulty and absence of switching, it is reasonable to assume that firms played an essentially static one-shot game to attract market share at the start of the system. Figure I plots the level of agents in the market over time; the average as well as the maximum across Afores. Both statistics decline substantially after the inception period. Figure II shows the average and median flow and balance fees across Afores. Both are nearly constant if not slightly increasing. It is clear that Afores recruited account holders while expecting to hold them going forward. As noted above, this belief was borne out by the near absence of switching. Afores substantially reduced their sales force numbers after the first two years of the system and could then hold fees roughly constant.

\section{Data and Descriptive Statistics}

\subsection{Data}

We compile data from several sources to form a detailed picture of workers' characteristics, pension fund balances and contributions, fund administrator choices, Afores' prices, and deployments of sales agents across localities. We use administrative data stripped of individual identifiers and provided under a confidentiality agreement with CONSAR. The data include each contribution made into each account on a bimonthly basis from 1997 to 2007 for all workers in the system as well as their account balance at the start of the system (imported from the SAR 1992 system). The data record gender and date of birth, which allow us to construct 
age and future date of retirement. The data also include the zip code of residence for most workers, which we use to link workers to measures of sales force concentration by Afore and geographic location.

We use the contribution and balance data to calculate the expected cost to every worker of placing her account under the management of each Afore. We do so by computing the average contributions (earnings and days worked in the formal sector) in each year going forward for workers with very similar baseline characteristics to the worker in question. We use this expected cost measure rather than the worker's actual realized costs because it avoids the measurement error and potential endogeneity biases associated with using realized values (Hyslop and Imbens (2001)). ${ }^{11}$

We construct local measures of sales force deployment and exposure using the official agent registration database from CONSAR. This registration panel provides us with monthly information from 1997 to 2007 on all agents (registration is required): their status (e.g. active or inactive), the Afore they worked for, and a zip code of work. Our data do not record which sales agents contacted which individuals, but the administrative accounts data do record which agent was responsible for bringing in each account. We observe in these data that agents are most likely to recruit individuals who live in their municipality (municipio). Hence we define municipality as the geographic market of interest. ${ }^{12}$ Our measure of workers' exposure to local sales force activity is the ratio of the number of agents in each municipality to the number of social security account holders in that municipality.

We complement these data with additional statistics on accounts' annual returns and investment vehicles, Afore ownership structure, and historic bank branch data by municipality from the late 1990's to early 2000's from the archives of Mexico's National Commission of Banking and Securities. ${ }^{13}$ We augment our findings with the aforementioned household retirement savings survey conducted in 2010-2011. This includes information on savings behavior, labor force participation, education, family structure, financial literacy, and knowledge of Afore and savings system characteristics (see Hastings and Wilson 2017 for details). While these survey data were obtained more than a decade after the system's inception, they are linked to and randomly sampled from the administrative records and therefore offer useful context to our analysis.

\footnotetext{
${ }^{11}$ Online Appendix Section 3, describes the expected cost construction in more detail. For our demand analysis we will use this cost, following the literature analyzing markets where prices for products may vary with expected usage (See for example, Miravete 2003, Heiss et al. 2010, Abaluck and Gruber 2011, Handel 2012, Einav et al. 2013, Grubb and Osborne 2012, Jiang 2012, and Duarte and Hastings 2012). A priori, fund manager choice is much less like likely to cause future labor force participation than health care plan choices are to cause subsequent use of different health services or cell phone plan choices are to cause calling behavior.

12 Because we know both the worker's zip code of residence and the sales agent's zip code of work registration, we can measure the typical distance between agents and the workers who "sign" with them. We found that the probability of having a worker using a sales agent in their same zip code is small (0.05), suggesting this is far too narrow an area to consider a market. Matches become more systematic, however, at higher levels of aggregation. The probability of a worker signing with a sales agent from the same county is about 0.40 . This suggests the municipality is capturing most of the geographic match between sales-force and their customers.

${ }^{13}$ http://portafoliodeinformacion.cnbv.gob.mx/bm1/Paginas/infoper.aspx.
} 


\subsection{Descriptive Statistics}

The positive relationship between sales force, demand, and price is apparent in raw aggregate statics. Table I shows Afores' flow and balance fees, national market shares, and the size of their sales forces. Afores are sorted in descending order by sales force size. Several patterns stand out.

First, there is substantial price variation in this market even though all the firms were large, wellknown institutions selling essentially homogenous, regulated investment products (Duarte and Hastings 2012). Many Afores are dominated in cost terms by other choices, meaning both their flow and balance fees are higher than both the flow and balance fees of at least one other Afore. For example, Santander charges a $1.70 \%$ flow fee (a $26 \%$ implied load on contributions) as well as a $1 \%$ balance fee, and is dominated at least by Banamex and Bancomer, which both charge the same high load fee but a zero balance fee. Those three firms' fees are dominated in turn by several firms who charge lower load fees and zero balance fees.

Second, the highest-fee (“dominated") firms have the highest market shares. The three firms mentioned above, Santander, Banamex and Bancomer, had the three highest market shares at inception. This is consistent with the classic brand value effect-workers perceived these Afores to have a product of high enough quality on non-price/non-return attributes to garner large market shares despite high fees.

Third, the final column of the table, we see that the high-fee, high-share firms are also those with high numbers of sales agents, suggesting that advertising had the effect of building brand value rather than increasing price sensitivity. In particular, Santander had the second largest market share and the largest number of sales agents among all Afores while simultaneously having both higher flow and balance fees than several competitors. Overall, the correlation between Afore market share and the size of its sales force is 0.79.

Table II shows descriptive measures of price sensitivity. Columns 1 and 2 repeat the number of sales force and market share of accounts statistics from Table I. Column 3 shows the mean cost ranking for each chosen Afore across its clients (rank 1 to 17, with 1 being the least expensive Afore for a given individual). Column 4 shows the mean cost ranking for each Afore over all people in the system. If individuals choose Afores mainly for lower management fees, we would expect the values in column 3 to be lower than those of column 4. They are not. Rather, the two columns closely resemble each other despite large variation in the relative rank for most Afores across workers.

Overall, the average rank is very high for Afores with substantial market share such as Santander, Profuturo GNP, and Banorte, suggesting that investors' Afore choices were driven by factors other than the fees they would pay. Interestingly, one of the highest cost Afores on average is XXI (Twenty-one), the Afore that is co-branded with the Mexican social security system, IMSS. This is reminiscent of findings for AARP co-branded Medicare Part D plans (Abaluck and Gruber, 2011; Mullainathan et al. 2012a). 
Column 5 calculates the mean "mark-up" that the average client in each Afore pays relative to what they would have paid had they chosen the cheapest Afore for them. Mark-up is calculated for each client as the expected cost in their chosen Afore minus the expected cost in the cheapest Afore for them, divided by the expected cost in the cheapest Afore for them. A value of 1.9 for Santander means that the average Santander client was paying 190\% more than they would have paid if they had chosen the cheapest Afore for them.

Column 6 translates this mark-up into a "days of salary” measure. It shows the average number of days' wages that could be saved by workers if that Afore's clients switched instead to the Afore that was cheapest for them. (These savings are calculated over a ten year horizon or to retirement, whichever comes first; a ten year horizon is a natural target holding period based on current structures in the Mexican and Chilean privatized pension fund systems — each now has a multiple-fund system that moves workers into funds with lower regulated risk at approximately 10 year age intervals). This represents the number of days Mexican employees work simply to pay the extra fees charged by their chosen Afore. They are non-negligible and suggest that real money is at stake and that demand may not be very price elastic, particularly for Afores with high levels of sales agents.

Columns 7 and 8 show the average daily wage of clients as well as the fraction of clients who are male. Higher wage clients tend to pay lower mark-ups. The final row of Table II shows the correlation between each column and the total number of agents. Across Afores, sales force is strongly positively correlated with market share as well as mark-up and potential savings from switching. Taken together, this suggest that demand was inelastic — high cost firms had high market shares—and this inelasticity was positively correlated with total sales force size. Note that total sales force are negatively correlated with the mean wage of the clients, suggesting that sales force could have a stronger influence on demand of lowerincome clients. Our model and estimates will speak directly to the impact of sales force on choices and outcomes across the income distribution.

Figure III provides a visual of the descriptive statistics in Table II. It plots mean mark-up for each Afore versus total sales force, with the marker size proportional to the Afore's market share. There is clearly a positive relationship between mark-up and sales force. Moreover, higher market-share Afores are predominantly in the higher-mark-up, higher-sales-force region of the graph. This graph suggests a persuasive and price-competition-reducing impact of sales force advertising.

We also see a similar high-cost/high-share/high-sales-force pattern examining across municipalities. We calculate Afore market share by municipality and the mean cost ratio for each Afore's clients (equal to the cost of the chosen Afore relative to the average cost of all Afores). In Figure IV we show that we find a positive and significant relationship between mark-up and market share, and this relationship is increasing in measures of sales force exposure. Figure IV plots demographic-adjusted correlation between mark-up and market share for each municipality versus the mean Afore's sales force concentration (sales force 
concentration is defined as total sales force per 1000 potential clients). Two things are important to note. First, the majority of correlations are positive, meaning that within most municipalities the correlation between mark-up and market share is positive. Second, the correlation becomes more positive on average as the means sales force per thousand potential clients increases.

While these descriptive statistics suggest that sales force contribute to low price sensitivity and high fees, we must take more care to infer a causal relationship. Afores could send sales force to areas where they expect higher (lower) demand and lower (higher) price elasticity, leading to an upward (downward) biased estimate of the impact of sales force on demand. To estimate the causal impact of sales force on preferences and demand, we exploit individual and geographic detail in our data, using a model of demand and sales force supply to motivate instruments for sales force and to estimate parameters of interest.

\section{Model and Estimation Approach}

\subsection{A benchmark model}

We develop a model that rationalizes a simple conditional logit specification for an investor's Afore choice and captures key features of firm and investor behavior described in Sections 2 and 3. In light of the institutional facts discussed in Section 2, we present a stylized benchmark model in which sales agents can be viewed as individual sales outlets, or “mobile kiosks” dispersed around geographic markets. This model generates an easily estimable econometric specification motivating our main empirical specification.

Let Afore $j$ employ $N_{j}$ agents in a geographic market. Agent $A_{j}$ represents the Afore, $j$, that she works for and whose fund she attempts to sell to investors. A client investor $i$ who chooses Afore $j$ receives a utility associated with the Afore along with an agent-client specific “match utility.” This match utility can simply reflect the physical distance between the agent and the client, the quality of the idiosyncratic interaction between the parties (as reflected, e.g. in the TV advertisements emphasizing finding the "right” Afore), or even whether the client ever became aware of this particular agent. Hence, we model the indirect utility that client $i$ receives from buying Afore $j$ from agent $A_{j}$ as:

$$
u_{i A_{j}}=\lambda_{i} C_{i j}+\delta_{j}+\varepsilon_{i A_{j}}
$$


where $\varepsilon_{i A_{j}}$ is the "match utility" between the agent $A_{j}$ and client $i$; $C_{i j}$ is the management cost for $i$ at Afore $j$, which depends on the client's expected future wage profile, incoming balance and $j$ 's flow and balance fees; $\delta_{j}$ accounts for all the non-cost components (e.g. expected return, brand value, availability of bank branches and complementary services, etc.) of Afore $j$. The elements of $\delta_{j}$ observed by clients are not necessarily those observed by the econometrician.

Given this indirect utility specification, and assuming that $\varepsilon_{i A_{j}}$ is drawn iid from a Type 1 Extreme Value distribution, ${ }^{14}$ the probability that client $i$ buys from Afore $j$ becomes:

$$
\operatorname{Pr}(i \text { chooses } j)=\frac{N_{j} \exp \left(\lambda_{i} C_{i j}+\delta_{j}\right)}{\sum_{k} N_{k} \exp \left(\lambda_{i} C_{i k}+\delta_{k}\right)}
$$

which can be rewritten as:

$$
\operatorname{Pr}(i \text { chooses } j)=\frac{\exp \left(\lambda_{i} C_{i j}+\delta_{j}+\ln \left(N_{j}\right)\right)}{\sum_{k} \exp \left(\lambda_{i} C_{i k}+\delta_{k}+\ln \left(N_{k}\right)\right)}
$$

Thus, we obtain an observationally equivalent indirect utility representation

$$
\tilde{u}_{i j}=\lambda_{i} C_{i j}+\tilde{\delta}_{j}\left(N_{j}\right)+\varepsilon_{i j}
$$

where the non-cost “intercept” component of the utility $\tilde{\delta}_{j}\left(N_{j}\right)$, depends explicitly on the number of agents that Afore $j$ employs in the geographic market.

Note that the above model also encompasses a pure "consideration set" model in which the role of sales agents is to increase the probability that a client will consider the Afore that they are affiliated with. ${ }^{15}$ In such a model, sales force does not have a "persuasive” role, only an informative role. An alternative model generating equation (3) is that agents are simply passive sales outlets who are spatially differentiated, without any informative or persuasive role, and the $\ln \left(N_{j}\right)$ term merely reflects the "density" of Afore $j$ in the space surrounding client $i$. Thus, the "intercept" term $\tilde{\delta}_{j}\left(N_{j}\right)$ in the indirect utility equation allows for explanations where larger numbers of agents generate higher utility/convenience for clients or make their Afore more

\footnotetext{
${ }^{14}$ We allow $\varepsilon_{i A_{j}}$ to have a common component within Afore $j$ across agents, with the Afore-specific common component absorbed into $\delta_{j}$, which is a demographic-geographic cell-level fixed effect. Thus the correlation would be at the demographic-geographic cell level. ${ }^{15}$ Models in which advertising helps to place products in a consumer's consideration set have been utilized by, e.g., Goeree (2008). To achieve an equivalent econometric specification as these models, we could, for example, replace the $N_{j}$ and $N_{k}$ in Equation (2a) with a "probability of sampling $j$ " term, $\pi_{j}=N_{j} /\left(N_{1}+\ldots+N_{J}\right)$.
} 
salient and likely to be considered. Both explanations assume that once a client considers an Afore, they observe costs correctly, and make a choice based on fund characteristics and relative importance they intrinsically place on those characteristics.

\subsubsection{The Effect of Sales Force Exposure on Cost-Sensitivity}

In our benchmark model, which can encompass both a consideration set and spatial differentiation interpretation, the cost or "slope" component of the indirect utility, $\lambda_{i}$, does not depend on sales force exposure. In econometric specifications, however, one can and we do, allow $\lambda_{i}$ to depend on the intensity of agent deployment in a market. If cost information is difficult to obtain or process, informative agents may make clients more or less cost-sensitive.

If agents financially educate consumers or make fees easier to find and understand, then in observably similar markets where (exogenously) larger numbers of such informative Agents are employed, we would expect that more agents raise cost sensitivity. It is also possible for clients' cost sensitivity to decline with increased exposure to sales force. This would be difficult to rationalize with a model in which agents' role is to provide correct information about Afores' costs; however, it is consistent with a model in which agents provide incorrect information or otherwise obfuscate costs (e.g. Gabaix and Laibson 2006; Ellison and Ellison 2009; Carlin 2009) and with audit and advertisement studies documenting such obfuscation (Bertrand et al. 2010; Mullainathan et al. 2012b; Gurun et al. 2015).

The more difficult clients find calculating the Afore-specific cost $C_{i j}$ that will accrue to them, the noisier are the perceived costs upon which they would actually base their choices, and the less sensitive to actual costs they will be. To illustrate, consider an extreme case where clients know their $C_{i j}$ values perfectly before meeting an agent but agents introduce noise or doubt about these costs per the advertisements described in Section 2. Assume that where (exogenously) more agents are involved, the variance of noise is higher. ${ }^{16}$ This would, in effect, create attenuation bias in our econometric specification (we utilize the client's true $C_{i j}$ for estimation, but clients make choices with noisy cost measures). We would find lower cost sensitivities in observably similar markets where (exogenously) larger numbers of “obfuscating” agents are operating.

Alternatively, or in addition, sales force could persuade consumers to care more about the non-cost attributes of the retirement product compared to its cost through, for example, sales tactics that minimize the importance of compounding or convince individuals that low costs do not translate into higher wealth at retirement (e.g. returns are important instead). In this case, agents act on clients' cost sensitivities directly rather than on their perception of costs. Both models - impact on cost perception or valuation of costs - are

\footnotetext{
16 This example is motivated by the model of Carlin (2009), who offers an example of oligopolistic financial product sellers who choose both prices and "complexity," where higher equilibrium levels of complexity results in a greater share of price insensitive consumers that support non-zero margins even in a homogeneous good market.
} 
observationally equivalent. In the context of a discrete choice framework, heterogeneous errors in variables and heterogeneous preferences are in general not separately identified (Borghans et al. 2008; Train 2013).

Because multiple mechanisms may be consistent with our data and model, and we do not have survey data on individual-level price perception or valuation before and after sales force exposure, we will not take a stand regarding the specific micro mechanism(s) that underlie the effects of sales force on investors' revealed preferences and price sensitivity. Indeed, we also refrain from conducting explicit welfare calculations based on our demand-side estimates, as the different models discussed above may have very different implications about welfare. Generally, mixed-methods approaches which combine stated perceptions surrounding advertising exposure and resulting choices are needed to shed further light on exact psychological mechanisms (e.g. Karlan 2005; Ashraf et al. 2006; Fehr and Goette 2007; Ashraf et al. 2010; Jensen 2010; De Los Santos, Hortaçsu, Wildenbeest 2012; Hastings et al. 2015a; Hastings 2016; Honka, Hortaçsu, Vitorino 2016). However, such data are typically not available at scale, making it difficult to measure market impacts and simulate policy counterfactuals as we are able to do with market-wide micro data. To the extent we focus on any "social outcome" in the analysis below, it is on the total management fees paid by workers in the forced savings-for-retirement system. Strictly speaking, these are transfers from the workers to the Afores and as such represent no net change in social welfare. However, much of the political and policy discussion around privatized systems focuses on the total costs of a system for distributional or other reasons, and as such we feel is worth explicitly quantifying.

\subsection{Estimation and Identification}

\subsubsection{Estimating Demand Parameters}

To estimate a tractable version of (3) and allow for flexible preference heterogeneity among investors, we follow a two-step approach. First, we estimate conditional logit models separately using demographic-bygeographic cells, and then estimate the impact of sales force on the resulting preference parameters using least squares and instrumental variables.

We break the population into 32 demographic groups, categorized by age (of which there are four categories), gender, and wage quartile. These demographic groups are interacted with investors' municipality (county) of residence. This yields 3,699 distinct demographic-group-municipality cells. For each demographicgroup-municipality cell, we use data on individual choices to estimate the following random utility model:

$$
u_{i j}=\left(\alpha_{c}+\gamma_{c} w_{i}\right) C_{i j}\left(y_{i}, b_{i}, p_{j}\right)+\delta_{c, j}+\varepsilon_{i j}
$$


where $\alpha_{c}+\gamma_{c} w_{i}=\lambda_{i}$, the cost sensitivity parameter. Using equation (4), we estimate for each demographicgroup-and-municipality cell a portion of utility that varies with management cost (the first term), and a mean value for each Afore which includes all characteristics of the Afore, both observed and unobserved to the econometrician. ${ }^{17}$ We can then use the thousands of resulting utility parameter estimates for $\lambda_{i}\left(=\alpha_{c}+\gamma_{c} w_{i}\right)$ and $\delta_{c, j}$ to examine the impact of Afores' advertising/marketing efforts as measured in their ratio of sales agents to potential clients (sales force concentration) in each local market, $m$, on demand parameters of individuals in various demographic groups.

Going across demographic-group-municipality cells, we next estimate the following linear relationship between sales force exposure and price sensitivity,

$$
\alpha_{c}=\alpha_{0}+\tilde{\alpha} A_{c, m}+\sigma_{c}
$$

where $\alpha_{c}$ is the cell-specific estimate of mean price sensitivity, and $A_{c, m}$ is a measure of total sales-force concentration in municipality $m$ corresponding to cell $c$ for all Afores. Additional specifications include demographic group dummies, cuts by demographic groups, and differential impacts of sales force from different Afores. Standard errors are clustered at the municipality level.

We estimate the impact of sales on brand value as

$$
\delta_{c, j}=\delta_{c}^{0}+\tilde{\delta} a_{c, m, j}+\beta X_{c, m, j}+v_{c, j}
$$

where $\delta_{c, j}$ is the cell-specific estimate of mean brand value; $\delta_{c}^{0}$ is a cell-specific intercept, $a_{c, m, j}$ is a measure of total sales-force concentration in municipality $m$ for Afore $j ; X_{c, m, j}$ are other characteristics of the Afore such as bank-branch concentration that can vary at the Afore and municipality level, and $v_{c, j}$ is a mean-zero residual value of Afore $j$ to the average investor in cell $c$.

Note that equation (6) departs from the "benchmark" model generated equation (3) in two important ways. First, as discussed in Section 4.1.1, we allow investors' cost-sensitivity to depend on sales force exposure. Second, the specification uses a linear function of sales force concentration. Sales force concentration is measured as number of sales force per thousand potential clients (as measured by formal sector workers) to capture the fact that sales agents will be more likely to make contact with a particular potential client the fewer the clients and informal or government sector workers there are. We use a linear

\footnotetext{
${ }^{17}$ Note that within a cell, price sensitivity $\lambda_{i}$ is allowed to vary linearly with individual $i$ 's current wage, so that price sensitivity varies smoothly with a measure of income within income quartile, age quartile, gender and county of residence.
} 
specification to include municipalities where there are zero sales force. This is an important end point in our sample as we focus on simulations involving setting the impact of sales force to zero in subsequent sections. Estimating (6) using the log of sales force yields qualitatively and quantitatively similar estimates of the impact of sales force on $\delta_{c, j}$, even though it excludes observations with zero sales force. Estimating the model using a quadratic in sales force concentration also yields qualitatively and quantitatively similar results.

\subsubsection{Sales Force Endogeneity and Instrumental Variables Strategy}

Sales force may be correlated with unobserved components of preferences for Afore $j, v_{c, j}$. We develop an instrumental variable strategy motivated by a model of sales force deployment choice.

Afores choose the number of agents to hire in a market based on the expected marginal revenue and the marginal cost of hiring an agent. Let $q_{i, j, m}$ be the probability that $i$ chooses Afore $j$ from equations (2b) and (3). This probability is a function of the number of sales force $j$ hires in market $m, N_{j, m}$, the hiring decision of competitor Afores in municipality $m, N_{-j, m}$, prices for $j$ and its competitors, $p_{j}$ and $p_{-j}$, the vector of individual

preferences, $\beta_{i}$, and personal characteristics, $\theta_{i}$, for individuals in market $m$. Let $\operatorname{Pr}_{i, N_{j}, m}$ be the probability that the agent from Afore $j$ finds and engages in a dialog with (delivers a sales pitch to) investor $i$ in municipality $m . T_{m}$ is the total number of individuals the marginal sales agent can approach and engage given time constraints. Agents are paid a base salary plus commission. Let $m c$ denote the marginal cost of sales agents based on the commission rate $\tau_{j, m}$, the base rate base $_{j, m}$, and other cost factors such as available hiring and screening staff and office space $\kappa_{j, m}$. Afore $j$ will hire sales agents in municipality $m$ until the expected increase in revenue equals the marginal cost:

$$
\sum_{i \in T_{m}} \operatorname{Pr}_{i, N_{j}, m} \frac{d q_{i, j, m}\left(N_{j, m}, N_{-j, m}, p_{j}, p_{-j} ; \beta_{i}, \theta_{i}\right)}{d N_{j, m}} C_{i j}-m c\left(\tau_{j, m}, \text { base }_{j, m}, \kappa_{j, m}\right)=0
$$

To identify the impact of sales force on individual $i$ 's preferences for price and Afore $j$ 's mean characteristics (brand name, etc.), we need instruments for $j$ 's sales force in $i$ 's municipality of residence which are arguably excluded from $i$ 's preferences for $j$. Equations (4) and (7) suggest three instruments.

First, sales force is increasing in average costs of account holders in the local geographic area, $\bar{C}_{j}$ (note that account holders' costs are Afores' revenues). Conditional on person $i$ 's demographics and personal costs, living in a municipality where members of other demographic groups are relatively high-revenue to Afore $j$ will increase $i$ 's exposure to $j$ 's sales force, all else equal. The individual considers personal factors when choosing an Afore, while Afores choose sales force based on market-level factors. The exclusion 
restriction is that the cost that neighboring investors pay for Afore $j$ enters $i$ 's utility function only through its impact on $j$ 's sales force decision and therefore $i$ 's sales force exposure. This is a classic advertising spillover instrument; the products a particular consumer is exposed to depend in part on the preferences of nearby consumers, even if there is no correlation between the preferences of this consumer and her neighbors (Waldfogel 2007).

Second, because sales agents were sent out to recruit individuals from the general population, a higher proportion of formal-private-sector workers (government workers and the self-employed do not participate in this system) in a particular demographic group should, all else equal, increase the yield rate per individual approached and the probability of a person with a SAR account being reached by a sales agent $\left(\operatorname{Pr}_{i, j, m}\right)$. If individuals with SAR accounts are easier to find per the recruiting strategies described in Section 2, yield rates per time spent should increase. To use the vernacular: holding fixed the number of needles (SAR account holders), smaller haystacks (fewer non-SAR workers) offer higher expected revenues to sales agents per individual approached.

Third, if having more local bank branches reduces costs of hiring sales agents, $\kappa_{j, m}$, then the number of bank branches in $m$ owned by competitor Afores, $-j$, changes the competitors' sales force decisions. This in turn shifts $j$ 's equilibrium sales force decision independently of client $i$ 's preferences for $j$ absent sales force. The exclusion restriction is that $-j$ 's branch concentrations do not enter $u_{i j}$ directly, only $j$ 's bank branch concentration directly affects investor's brand value for $j$.

We present results using combinations of these three instruments. The results are consistent across specifications.

Hence we instrument for sales force

$$
N_{c, m, j}=a_{c}+\beta Z_{c, j}+\omega_{c, j}
$$

where $Z_{c, j}$ is a combination of the instruments described above: an advertising spillovers measure, the share of the municipality working-age population for cell $c$ that has formal-sector pension benefits, the share of municipality working-age population employed in the formal public (government) sector, and the bank branch concentration of other Afores. We interact each instrument with Afore dummies to allow the impacts to vary across Afores.

Note that we could estimate the utility parameters in one step using a simple transformation of the market share for each Afore in each demographic-municipality cell as a dependent variable and instrumenting for sales force in a similar way (Berry 1994). However, doing so would implicitly assume that all individuals in a demographic group and municipality face the same relative costs for each Afore, which does not hold in 
our data. Using individual choice data adds a step to the estimation, but allows us to take advantage of variation in personal costs to identify price sensitivity as well as provide added instruments and exclusion restrictions to identify the impact of sales force on demand.

Our advertising spillover instrument rests on an assumption that person $i$ 's idiosyncratic preferences for Afore $j$ are uncorrelated with the relative cost of $j$ to other demographic groups living in $i$ 's municipality. As a check, we estimate the correlation between mean costs (i.e., mean Afore revenues) of individuals in each demographic group with the mean costs of other demographic groups in their municipality for each Afore. In regressions of $\bar{C}_{c j}$ and $\bar{C}_{-c j}$ run separately by Afore, we find $\mathrm{R}^{2}$ ranging from 0.001 to 0.006 across Afores. Therefore, the observable profitability of workers in one demographic cell is essentially orthogonal to the observable profitability of other demographic cells in the same municipality. If, as is plausible, observable and unobservable profitability factors are correlated, this low correlation between own and average-neighbor's costs implies that the unobservable components of profitability are also likely uncorrelated (Altonji et al., 2005).

\subsection{Estimation Results}

Table III shows the results of regressing our cell-level estimates of Afore-specific brand effects $\delta_{c, j}$ on measures of sales force for Afore $j$ in municipality, $m$. We use the number of sales agents for Afore $j$ in municipality $m$ divided by the total number of SAR affiliates (workers) in $m$ (in thousands) as our measure of sales force exposure. Hence our measure is the number of sales agents per 1,000 potential clients in a given municipality. We also allow Afore brand effects to vary with the Afore's municipality-level brick-and-mortar bank branch presence (measured as number of branches per 1,000 adults), and an indicator if the Afore is a bank, as bank branch data are only available for banks.

Column 1 presents OLS estimates with standard errors clustered at the municipality-Afore level. Column 2 presents instrumental variables estimates using the advertising spillovers instrument (mean costs in same-municipality-other-demographic-group cells for Afore $j$ interacted with Afore fixed effects). Column 3 adds competitor bank branches in the municipality and its interaction with Afore fixed effects as instruments. Column 4 adds fraction of the working-age cell population who are IMSS account holders interacted with Afore fixed effects as an additional instrument. (The first-stage F-statistics are reported in Table III.)

The OLS impact of sales force concentration on brand value is positive and significant, in line with the market share correlations presented in Figure II. IV estimates are larger than the OLS estimates for all specifications, indicating that Afores send sales force to areas where their baseline brand value is lower rather than where the customer base is already brand-captive. This is consonant with predictions from equation (7) if 
areas with lower baseline brand value for $j$ are areas where $j$ 's marginal sales agent can have a larger impact on demand. Using the point estimate from column 2, a one standard deviation increase in sales force (0.312) would increase an Afore's brand value by $51 \%$ of the mean, all else equal. In comparison, a one standard deviation increase in bank branches per thousand adults would have a 7.9\% increase on an Afore's brand value. Bank-run Afores per se have a higher mean value to investors, equivalent to about a third of a standard deviation increase in sales force. This is more likely attributable to familiarity and street presence than to a desire to have banking and SAR accounts at one institution, as the large majority of SAR account holders save in co-ops and credit unions, and less than $15 \%$ of surveyed SAR participants list unified banking as one of the top three reasons for choosing their current Afore (Hastings and Wilson 2017). All of the major banks operating in Mexico entered the Afore market.

Table IV presents instrumental variables results by demographic groups using the full set of instruments from Table III, column 4 (similar results are found using the instruments in columns 1 and 2 of Table III). Sales force concentration has a 26\% larger (4.598/3.660) impact on brand value for low income workers than for high-income workers (defined as above median daily wage). Bank branch presence has about half the value to low-income workers. This makes sense as low-to-middle income workers are much less likely to save in a bank (Hastings and Wilson 2017). Sales force have a similarly larger impact on men's valuation of Afore brands relative to women's. Younger workers are more affected by sales force than older workers, while older workers value local branches slightly more.

Note that because we only observe data on sales force deployment, and not on which individuals each sales agent approached and the outcome of each sales attempt, higher impacts of sales force by subgroup could be either because the individual was more responsive to a received sales pitch or because sales force targeted them more often for approach. We can look at whether sales force characteristics (zip code location and age) vary systematically with individual characteristics of those accounts for which they signed up (recall the data do record which sales agent was responsible for signing which account). Systematic differences would indicate selective targeting. We do not find evidence of this; geographic proximity and age of sales agent are nearly identical across individuals of different incomes, genders, and ages.

We also create an indicator if an Afore is one of the four lowest-cost (lowest-quartile) Afores for account holders in a demographic-group-municipality cell. We label these "Low Cost” Afores. Because costs vary based on local demographic and labor profiles, the identity of the Low Cost Afores varies from cell to cell and county to county. Each Afore appears as one of the cheapest between 3\% and 15\% of the time. We test if Afores' sales agents have less of a persuasive effect on brand value in cells where the Afore is Low Cost, a possible indicator of Afores' sales agents emphasizing non-price attributes less when they held a price advantage. However, we find that sales force for Low Cost Afores has a similar effect on brand value to that of other Afores within a cell; it does not seem that the lower-cost Afores market themselves this way. 
Table V examines the impact of sales force on estimated price sensitivity in an OLS regression of $\alpha_{c}$ on total sales force concentration (summing across all Afores within a municipality). ${ }^{18}$ The findings further support the view that sales force makes investors less sensitive to costs. Overall exposure to sales force increases $\alpha_{c}$ towards zero (i.e., reduces price sensitivity). The estimates in column 1 imply that a one standard deviation increase in total sales force concentration (2.504) reduces the absolute value of $\alpha_{c}$ by $30 \%$ $(0.046 * 2.504 / 0.388)$. Column 2 allows for a separate additional effect of sales force concentration for the cheapest four Afores. The coefficient is negative but insignificant and half the magnitude of the level effect, indicating that agents of lower-cost Afores are following a strategy with significantly different impact on investors. Columns 3 through 8 estimate the impact of sales force by demographic group. The decrease in price sensitivity is stronger for low-wage workers, men, and younger workers- the same groups for which sales force had stronger persuasive impacts on brand value.

Taken together, Tables IV and V support a view of advertising where Afores' sales forces acted through two channels: first, to decrease price sensitivity and, second, to increase the salience of the brands they each represent - thus rotating and shifting out demand for the Afore that hired them. This was particularly true among men, younger workers, and lower-income workers.

Utility parameters are difficult to directly and quantitatively interpret as they are unitless and work together (rather than separately) to determine choice and demand elasticity. To quantify the magnitude of the impact on Afore choice and management costs paid, we use our parameter estimates to compute counterfactual demand elasticities and Afore choices in the absence of sales force impact on preferences. Counterfactual demand and elasticity estimates combine the demand-shifting and demand-rotating impact of sales force into a single measure of impact. To see this, note that our while our parameter estimates imply investor choice would be more sensitive to cost in the absence of the estimated sales force effects, the impact on the relative importance of each Afore's non-price attributes is less straightforward. (Non-price attributes could be brand, or any Afore attribute other than costs that is common across investors in a geographic-demographic cell). While investors are more likely to purchase from the Afore(s) whose sales force they encountered, in the absence of any sales force influence, the effect of Afores’ non-price attributes on investor choices reverts to $\delta_{c, j}=\delta_{c}^{0}+\beta X_{c, m, j}+v_{c, j}$. The variance of these brand effects across Afores in a given geographic-demographic cell may be larger or smaller than their values inclusive of sales force influences. Thus, while in the absence of sales force influence, value of non-price attributes will not vary with sales force, non-price attributes could vary relatively more or less in the counterfactual world with no sales-force impact on preferences. The

\footnotetext{
${ }^{18}$ Note that brand value may be endogenous with unobserved preferences for an Afore, per equations (5) and (6). However price sensitivity is identified off of differences in Afore price ranks across individuals controlling for brand fixed-effects at the cell level. Accordingly, we estimate equation (4) with OLS and note that instrumenting for sales force in this equation using the additional instruments in Table III column 4 does not change the parameter estimates.
} 
demand-shifting impact of sales force combine in non-linear ways to influence relative demand and equilibrium prices.

Figure V shows what the demand elasticity for each Afore would have been if the effects of sales agents on workers' preferences were set to zero. This graph is generated as follows. First we calculate the demand elasticity for each individual for each Afore using the observed prices, characteristics and sales force exposure levels. ${ }^{19}$ Then we take the average demand elasticity for each Afore across all individuals in the market. To quantify the impact of sales force on demand, we repeat this process after setting the estimated impact of Agents on price sensitivity and brand value to zero ( $\tilde{\alpha}$ and $\tilde{\delta}$ from equations 5 and 6 , respectively). We refer to this counterfactual as the "Neutral Agents" counterfactual, as it imposes that sales force has no impact on price sensitivity or brand value. (To do this, we also zero out the impact of sales agents for Garante, the reference brand value Afore.) This counterfactual is not meant as an evaluation of an alternative policy as it does not incorporate a supply-side response (though we do this in Section 5), but rather as a way to quantify the demand-side impact of sales force on investors’ Afore choices.

Figure V plots the mean elasticities for each Afore at the demand estimates (Base Model) and at the Neutral Agents counterfactual against mean sales force concentration. Online Appendix Table II presents tables of mean elasticities and market shares under each model. The model fits extremely well in sample; the actual shares and predicted shares from the Base Model are almost identical. Figure V shows that baseline elasticites calculated at the demand estimates are on average negative, but less than one in absolute value, with the exception of Bancrecer/Dresdner/ HSBC. This implies that the average investor has inelastic demand for each Afore when evaluated at current prices, characteristics, sales force exposure and estimated preferences. ${ }^{20}$

In contrast, demand is substantially more price elastic under the Neutral Agents counterfactual. The average price elasticity more than doubles. There is also nontrivial variation in the size of the increase in the elasticity across Afores; overall those Afores with the largest sales force concentration show the largest increase in price elasticity between the baseline model and the Neutral Agents counterfactual. This suggests that a substantial portion of the price insensitivity in the market can be attributed to the impact of sales force on choices; without this effect, demand would have been much more elastic across the board.

While we cannot determine if, in the absence of sales force, worker's price perception would have been correct (e.g. unbiased estimates of expected costs), or whether workers would have placed correct

${ }^{19}$ Demand elasticity is $\frac{C_{i j}}{q_{i i}} \times \frac{\partial q_{i j}}{\partial C_{i j}}$ where $C_{i j}$ is the management cost as defined above, and $q_{i j}$ is the choice probability given by the logit demand equation. We hold cost constant and calculate this elasticity at the parameter estimates as well as in the counterfactual case where sales force has zero impact on preferences.

${ }^{20}$ These elasticities are averaged across investors without weighting each investor by their potential revenue. They summarize individual behavior, but do not correspond to the objective function of the Afore. The Afore would weight each individual by expected revenues, as the elasticity of each peso, not each person, is what matters for revenue. Preferences of those with larger potential accounts matter more for Afore's optimal fees. 
(unbiased) weights on price versus non-price attributes, we note that the impact on demand elasticity is similar in size to impact estimates from mandatory fee disclosures, such as the one implemented by CONSAR in 2005 and analyzed in Duarte and Hastings (2012). In that case, the government created a specific fee index from the flow and balance fees, and required a standardized table of fees to be shown by agents to customers at the time of sale. It required a signature from the customer stating they read and understood the simple comparative fee table. Duarte and Hastings (2012) show that this had an impact on demand elasticity similar to what we find here.

Finally, while we are able to estimate the impact of sales force on choices and the weight placed on management fees given our identification strategy above, we note that whatever impact television and print advertising discussed in Section 2.3 had on choices remains. Note that overall, the number of television advertisements registered for an Afore in the Neilsen-Ibope database is correlated 0.68 with total sales force, suggesting that sales force size is strongly positively correlated with Afores' broader sales and marketing efforts.

We can also simulate expected management costs paid from increasing price elasticity under the Neutral Agents counterfactual. ${ }^{21}$ Table VI presents simulation results of mean change in elasticity and percentage change in total cost paid ([Neutral Agents model cost / Base model cost] - 1) by demographic group. Overall, expected management fees paid in the system are 17.2\% lower under the Neutral Agents counterfactual. This is one way to quantify the impact of sales force on the price workers/investors paid: holding fees constant, it tells us how much less expensive the chosen Afores would have been if sales force had zero impact on preferences. This $17.2 \%$ decrease translates into an average of 48,054 pesos, a sizeable increase in savings for retirement. Using an approximation of 12 pesos per one USD, this is about \$4,000 in savings over ten years. To give additional context, note that the Mexican government guarantees a minimum monthly pension payment of 580 pesos per month for any individual who does not meet a minimum threshold of 1,092 pesos per month in income in retirement. Thus, the expected reduction in fees paid over 10 years translates into almost seven years of the minimum pension guaranteed by the government to alleviate poverty in old age.

Results by demographic group reveal several interesting patterns. First, although Tables IV and V showed a stronger percentage impact of sales force on preferences for low-income workers, in terms of costs, low-income workers gain the least (a 5.3\% reduction in total management costs) in our Neutral Agents counterfactual. This is because while sales force have a strong persuasive impact on choices among low-

\footnotetext{
${ }^{21}$ Expected costs paid by individual $i$ are simply the choice-probability-weighted management costs over a ten year horizon for person $i$ in Afore $j: E\left(C_{i} \mid \theta_{i}\right)=\sum_{j=1}^{J} C_{i j} q_{i j}\left(\theta_{i}\right)$ where $C_{i j}$ is the management cost, and $q_{i j}$ is the logit choice probability that $i$ chooses $j$ given preferences $\theta_{i}$. Preferences are held at our demand estimates and costs are calculated to get baseline expected costs. We then set the impact of sales force on preferences to zero and recalculate choice probabilities and expected costs.
} 
income workers, in the absence of sales force low-income workers would still pick high fee Afores based on brand-specific factors or idiosyncratic preferences. They are less demand-elastic in the absence of sales force; their simulated demand elasticity is the lowest among all of the demographic groups in both the baseline and the counterfactual. This is consistent with survey evidence from the 2010-2011 EERA showing that lesseducated and lower-income workers are less financially literate and less likely to know facts about their accounts and the savings and retirement system in general (Hastings and Wilson 2017). That said, even among low-wage workers, estimated savings are still substantial when compared the monthly pension guarantee payment. These workers are the most likely to receive a pension payment in old age for insufficient income and savings in retirement. Among this group, the savings over ten years are nearly a year of payments.

Overall, higher-wage workers benefit the most in the absence of sales force in terms of their percentage reduction in fees (men and older workers also benefit slightly more on average than women and younger workers). This is driven by the fact that when we zero-out the impact of sales force on preferences, higher-wage worker demand becomes very price elastic. The large implied effect of sales force on higherwage workers' choices may seem counterintuitive, as financial literacy is generally positively correlated with income and age (Hastings, Madrian and Skimmyhorn 2013). While higher earners may be more sophisticated in that they understand the fundamental importance of compounding and how fees and returns impact account growth, several studies show that they are also more likely to chase returns, over-emphasize brand, and ignore fees when brand or returns are emphasized. For example, Hastings and Tejada-Ashton (2008) use conjoint analysis experiments in a convenience sample of Mexican social security participants and find that while financially literate place more weight on fees when evaluating Afores, if also given information on returns, they lower the importance they place on fees and chase past returns instead.

Market concentration is lower in the Neutral Agents counterfactual because investors have weaker brand preferences. Market share drops the most among the market leaders (those with the largest sales force). Market share shifts to minor players with small sales force like Zurich, Principal and Capitaliza and to the moderately sized players with smaller sales force such as Inbursa and XXI. Overall, the Herfindahl-Hirschman Index (HHI) drops from 1,088 to 940 when the impact of sales force on preferences is zeroed out. ${ }^{22}$

\section{Policy Simulations}

\footnotetext{
${ }^{22}$ See NBER WP 18881 Online Appendix Section 1.
} 
The results above suggest that inelastic demand, caused in part by the impact of sales force, contributed to high fees and thus low savings for retirement. Several regulations are often proposed to accompany moves towards privatization: introducing a government competitor that charges a low price to “discipline” the market, regulating marketing, and undertaking campaigns to increase financial literacy and informed choices (i.e., the government invests in informative advertising).

The demand-side estimates suggest that these policies could have resulted in lower prices. However, drawing policy implications from demand-side evidence alone is complicated by the fact that firms' choices will respond to these policies. With data for the entire market, we can both identify and quantify the impact of sales force on demand and explore policy counterfactuals in a way that is often not possible. We develop a model of price setting and competition between Afores. We couple this model with our demand estimates to simulate counterfactual prices and management fees paid under the policy scenarios outlined above, allowing firm prices to adjust strategically to changes in policy and demand.

\subsection{Modeling Firm Price Decisions in a Regulated Social Safety Net Market}

We assume firms compete on prices, Nash-Bertrand, in a differentiated products market. ${ }^{23}$ Revenues for Afore $j$ are:

$$
\pi_{j}\left(f_{j}, b_{j}, A_{j}\right)=\sum_{i \in I}\left[q_{i j}\left(f_{j}, b_{j}, A_{j}^{i}, f_{-j}, b_{-j}, A_{-j}^{i} ; X_{i}, \theta_{i}\right) \times \sum_{i=1}^{T_{i j}} r e v_{i t}\left(f_{j}, b_{j} ; Z_{i t}\right)\right]
$$

where we sum over (expected) revenues obtained from each individual $i$ in the system. Here $f_{j}$ and $b_{j}$ are flow and balance fees set by Afore $j$; $A_{j}$ is the vector of region-specific sales force levels chosen by the Afore; $A_{j}^{i}$ is the level of sales force exposure for individual $i$ from Afore $j$ 's agents; $q_{i j}$ is the probability that individual $i$ chooses Afore $j$ given utility (per equation 3) as a function of fees, Afore characteristics, sales force exposure, personal characteristics, $X_{i}$, and preferences, $\theta_{i}$; and $r e v_{i t}$ is the present value of the revenue stream generated by individual $i$ in year $t$ assuming she does not switch to another Afore. The subscript $-j$

\footnotetext{
${ }^{23}$ We model the supply side as a static game even though competition may at first glance appear to have an important dynamic element: workers can switch Afores (though at a cost), creating switching-cost-driven dynamics. However, we are comfortable approximating the market as static because it turns out that, empirically, almost all switching of Afores by workers—which as discussed above occurred at a very low rate to begin with—is driven by changes in employment status (Duarte and Hastings 2012). That is, workers who do switch appear to being doing so in response to what occurs in the labor market, not competition among Afores. We therefore think of the arrival and departure of clients as being driven by an exogenous process; firms maximize profits take this process as given.
} 
denotes all Afores other than Afore $j$. Thus revenue is a function of $j$ 's fees, $f_{j}$ and $b_{j}$, and a set of personal characteristics, $Z_{i \cdot}{ }^{24} T_{i j}$ is the time horizon over which the Afore calculates profits from an individual. This is the minimum of the years to retirement for individual $i$ and a free parameter $T_{j}$ that we estimate separately for each Afore. Specifically, $T_{j}$ is the Afore's “profit horizon” - the horizon over which it calculates profits when setting fees.

Our specification with a profit horizon is motivated by the regulatory constraints and uncertainty in this and other policy-important markets (like pharmaceuticals or health insurance). We know that Afores made fee decisions under a regulatory approval process; they had to submit fees, along with a 10 year forecasted demand and profitability business plan to the regulator before being allowed to enter the market. Afores may have feared threat of regulation or been uncertain about the longevity of this new system (Argentina and Venezuela halted privatizations of social pension programs during the period of our analysis, for example). This regulatory threat may have affected their fee strategy (e.g., Glazer and McMillan 1992, Stango 2003). We therefore allow firms to vary in the time-horizon over which they calculate profits, $T_{j}$, to capture regulatory threat. This allows them to up-weight current revenues (that is, shift their relative fee structures toward flow fees and away from balance fees) if the future of the market is uncertain. Indeed, approximately 10 years after the inception of the system, the government regulated and capped fees. While our use of possibly varying profit horizons is nonstandard, it is useful to remember that in empirical supply and demand models there is typically one unknown factor, either marginal cost or conduct, which allows the model to fit the data. We believe that in this regulated setting, time horizons are a plausible additional feature of Afore conduct that the model can use to explain chosen prices. As the estimation results below reveal, varying profit horizons appear to have played an important role in determining market outcomes.

A Nash equilibrium of this game is a vector of balance and flow fees and regional sales force levels such that each firm’s choices are best responses holding other firms’ decisions as given. However, characterizing this Nash equilibrium for counterfactual parameter values is rendered computationally difficult due to the large number of regional sales force decisions that need to be made by each firm. Therefore, our analysis using the supply-side model is limited to situations that can be reasonably analyzed without re-solving for the regional sales force deployment decisions of the firms. Thus, in all of the analyses below, we either keep the sales force deployment levels fixed at their observed values, or we neutralize the effect of advertising by zeroing out the effect of sales force on preferences.

Given a vector of sales force levels $A$ and a vector of expected account horizons $\left(T_{j}\right)_{j \in J}$, a Nash-

\footnotetext{
${ }^{24}$ We set marginal costs of account management to zero. Afores' profits also include the costs of hiring sales agents. Including this term in our analysis would not change anything, as the counterfactuals we compute either leave marketing (i.e., agent) spending constant or shut it down completely. Hence we never need to know sales force hiring costs, as we do not need to compute new optimal sales force levels in any counterfactual.
} 
Bertrand equilibrium in this game is a vector of fees $\left(f_{j}, b_{j}\right)_{j \in J}$ such that

$$
\left(f_{j}, b_{j}\right) \in \arg \max _{\left(f_{j}, b_{j}\right) \in[0, \bar{f}] \times[0, \bar{b}]} \pi_{j}\left(f_{j}, b_{j}, A_{j}, f_{-j}, b_{-j}, A_{-j} \mid \mathrm{T}_{j}\right)
$$

for each afore $j \in J$, where $\bar{f}$ and $\bar{b}$ represent implicit regulatory approval caps on fees.

Note that firms’ maximization problems with respect to prices need not be convex in our setting. In markets with heterogeneous preferences and enough price-inelastic consumers, a firm may respond to a competitor's low price by ceasing to compete on price, raising price, and selling only to a small inelastic base. ${ }^{25}$ This discontinuous best-response function implies that instead of following the traditional methodology of estimating the supply-side parameters that minimize smooth, continuous first-order conditions given demand, we solve for the equilibrium using a best-response iteration algorithm (henceforth, BR iteration). This yields an intuitively appealing solution that survives the iterative best-response test. The Online Appendix Section 2 describes the algorithm and sensitivity analysis we performed to demonstrate robustness of our solution to initial starting points and simulation approach. To summarize, we use a Gauss-Seidel BR-iteration algorithm in which Afores simultaneously best respond at every iteration, and find no convergence issues in any of our numerical implementations. We conduct several robustness checks, including changing the order in which firms best respond as well as initial starting values. The solution found under the sequential bestresponse algorithm is robust across these checks. While our numerical solution does not preclude the existence of other equilibria not found under the sequential best-response algorithm, we show in the Online Appendix that the existence of an equilibrium where some Afores choose to compete for the individuals with inelastic demand and charge the highest possible fees (which is what we find in our analysis, as described below) eliminates the possibility of an equilibrium where firms compete for the majority of the account (i.e., an equilibrium where no firms best respond on the upper boundaries).

Online Appendix Table III shows the estimated time horizons $T_{j}$ for which simulated equilibrium fees best fit Afores' observed fees. The table also includes ex-post realized time horizons - the length of time the Afore actually remained in the market - out to ten years, simulated fees, actual fees, predicted market shares at the simulated fees, and actual market shares. The estimated equilibrium fees and market shares evaluated at the fitted time horizons are highly correlated with actual fees and market shares ( 0.80 to 0.98 correlation). This is

\footnotetext{
${ }^{25}$ Though this issue has not been incorporated in the prior literature, we note that such non-convexities in best-responses may be present in many traditional and social safety net markets outside of ours. For example, it would cause the "generic competition paradox" in the pharmaceutical industry, where generic entry can lead to higher brand-name prices (Frank and Salkever 1992, 1997; Berndt et al. 2003; Davis et al. 2004). It could also lead to mom-and-pop stores to increase prices in response to competition from WalMart, and could appear in voucher-driven competition between schools if demand is similar to Hastings, Kane, and Staiger (2010).
} 
much higher than if we force Afores to use a uniform horizon of 10 years; it is clear that most Afores charge flow fees that are far too high and balance fees that are too low to be consistent with a horizon of a decade or more. Moreover, the estimated time horizons also fit the data out of sample well; we generally predict short horizons for firms who ex post exited the market during the first few years of the system and longer horizons for the firms that remained.

\subsection{Counterfactual Results}

We use our supply-side parameters and the demand estimates from Section 4 to conduct several counterfactual policy simulations. The first counterfactual scenario we analyze completes the calculations in Section 4.3, but now allows prices to respond to the change in demand caused by zeroing-out the impact of sales force on workers' preferences. This measures the full demand-and-supply impact of “Neutral Agents” as we allow prices to readjust to the substantially higher demand elasticity and weaker brand-specific preferences. While this counterfactual does not reflect a particular proposed policy (such as introducing a government competitor), it quantifies the full contribution of sales force on equilibrium prices, and illustrates how increased price elasticities can affect equilibrium outcomes. Results are in Table VII. In contrast to the 17.3\% drop in costs in Table VI, total system costs fall by $62.1 \%$. Given that they now face substantially more elastic demand, Afores find it optimal to cut their fee levels substantially. As in Table VI, low-income workers' costs fall by less than high-income worker's costs (-55.5\% vs. - 64.3\%), due to the fact that they remain fairly price insensitive even in the absence of sales force impact on preferences. However, a substantially greater share of the cost savings accrues to lower-income workers here when firms must compete more aggressively on price. Table VII also presents mean pesos decrease in expected fees paid, and translates them into the number of years of minimum pension payments. Now, overall, the average expected fees that are saved per system participant is roughly equivalent to 31 years of minimum pension payments.

The next counterfactual scenario we analyze has XXI (the Afore which co-branded with the social security administration) behaving as a "public option” that charges a price near marginal cost in order to increase competition. We assume marginal cost pricing is a flow fee of zero and a balance fee of ten basis points ( $0.10 \%$ annually), fees typical of the most popular index mutual funds (e.g. Vanguard) in the U.S. Table VIII presents the simulation results. The first two simulation columns show the impact that XXI playing $(0.00$, 0.10) has on other Afore's prices, market shares, and management costs paid by different demographic groups under the assumption that sales force deployment levels and preferences are fixed at their observed levels (the Base Model). We find that a government player can have unintended consequences, leading to increased rather than decreased prices. This happens for two reasons. As noted above, the best responses may be complicated 
due to groups of very price inelastic customers. If a competitor such as XXI lowers its price, Afores may find it optimal to match price decreases up to a point. However, for large enough price cuts by XXI, an Afore's best response may be instead to charge a very high price to a captive base of inelastic customers. We find this does in fact occur.

We impose regulatory caps on fees and show results at each cap. ${ }^{26}$ In column 1 , we set the cap at $2 \%$ flow and $2 \%$ balance fee, even though currently fees exceed that on at least once dimension for some market participants. With this cap imposed, we find that overall fees decline only slightly, and all other firms price at the imposed regulatory cap. XXI's market share only increases from $2.7 \%$ to $5.8 \%$ despite having by far the lowest fees in the market. Column 2 shows that any modest cost savings in column 1 is driven by regulatory fee caps. If we allow the caps to increase to $3.2 \%$ flow fee and $5 \%$ balance fee, we find that approximately $21 \%$ of Afores respond to XXI by increasing their prices to the cap. Despite its low fee, XXI garners only $6.4 \%$ market share, while Afores pricing at the cap for at least one fee manage to win over $23.5 \%$ of the investors in the market. Because of this, having XXI act as a low-cost government option actually increases total cost paid in the market, rather than decreases it. The higher fees charged by firms who best-respond to XXI by increasing fees outweighs the low-fees paid by the relatively small set of elastic customers who choose XXI. For the most part, costs decline on average only among older workers, who on average have a higher baseline preference for the government-run firm. Importantly, costs increase substantially - by $20.0 \%$ - among low-income workers, as they are the most likely to be the inelastic subgroup of investors in Afores who raise fees in response to XXI's low prices. Thus in the absence of other policies, a government competitor could actually lead to higher prices being charged to low-income workers with low price sensitivities and who are strongly influenced by persuasive advertising.

Column 3 shows how the simulation results change under the assumption that the effect of sales agents on preferences has been zeroed out - the Neutral Agents assumption. Now, in the absence of persuasive advertising, XXI's share increases over 500\%, from 2.8\% to $14.3 \%$. Thus without the influence of persuasive advertising, a substantially larger fraction of customers choose the low-price government option. No firms best respond by pricing at the cap in this case. Overall, management costs in the system decrease by $64.0 \%$ as firms instead respond to price competition and elastic demand by lowering, not raising prices. Gains are large for all workers, as even the still-relatively-inelastic benefit from competition and lower overall fees. Therefore, inducing a critical amount of price elasticity can benefit all segments of workers. In fact, adding the government competitor does little to further lower fees (comparing $-62.1 \%$ from Table VII to -64.0\% here), as elastic demand in the absence of sales force sufficiently disciplines prices in the market.

\footnotetext{
${ }^{26}$ Private sector mutual funds in Mexico faced an annual fee cap of 500 basis points (5\%) of assets in this period (Institutional Investors in Latin America, OECD Publishing, 21 July 2000, p. 81).
} 
Neutralizing the impact of sales force on preferences is not a well-defined policy. However, the simulation results indicate that raising price sensitivity among low-income or price-inelastic market segments is key to improving price competition. This motivates our second counterfactual simulation: increasing price sensitivity in the marketplace. Financial illiteracy, for example, has been linked to consumer confusion and price insensitivity, prompting calls for increased financial education. These calls have made their way into sweeping financial reforms in the U.S. with the Dodd-Frank Act and the Consumer Financial Protection Bureau's Office of Financial Education. Hastings and Tejada-Ashton (2008) find that simplified information leads to a $25-50 \%$ increase in mean price elasticity measured from stated preferences in a convenience sample of account holders in Mexico. Duarte and Hastings (2012) show that a simplified fee index introduced in the system in 2005 (several years after the inception period we study here) and widely advertised by the government increased sensitivity to that measure of price fourfold or more.

We take these two estimates and interpret them as reflecting a direct change in price sensitivity among the most inelastic quartile of investors. To implement this counterfactual, we decrease $\lambda_{i}$, the coefficient on total costs in the indirect utility function, by one standard deviation for the least price sensitive quartile of the population. This increases the mean demand elasticity each Afore faces by between 50 and 75\% — substantial but not unreasonable given the results cited above.

Table IX, column 1 presents the results. Under this counterfactual, we find that total system costs decline by 33.9\%. This policy is much more effective at reducing costs than deploying a government competitor, but less effective than the hypothetical world with neutral advertising. Costs for low-income workers still decline the least, but now by a substantial $26.4 \%$. These workers are the most affected by the demand-elasticity-improvement.

The second column adds a government competitor. In contrast to Table VIII columns 1 and 2, no firms price at the cap, and costs decline by 38.9\%. Increasing price sensitivity among the most inelastic customers eliminated the profitability of responding to competition by raising price, as there are no longer enough sufficiently captive customers. High-income workers still benefit more in this case because they substitute in greater proportion to XXI.

Finally, for comparison, column 3 sets the impact of sales force on preferences to zero. All three changes combined (government competitor, targeted financial literacy education, and zeroing out sales force effects) lead to a 73.5\% decline in costs. All workers benefit from across-the-board declines in prices. To put this in perspective, we calculated costs if all Afores were forced to charge a $0.75 \%$ balance fee and no flow fee. (The average management fee for bond mutual funds in the U.S. at the time of the SAR inception was approximately 75 basis points.) Under such a uniform cap, total costs would be approximately $75 \%$ lower. Direct price regulation is often seen as a blunt or inefficient policy mechanism compared to designing markets 
to be more efficient based on economic behavior and principles (Lowenstein et al. 2014). In our simulations, demand side and supply side interventions bring estimates equilibrium fees in line with sensible benchmarks.

Overall, the results of the counterfactual simulations suggest that Afores' marketing efforts, particularly in the form of an agent-based sales force, contributed substantially to high equilibrium fees in Mexico’s social security system. Sales force had a substantial impact on price sensitivity, leading to high equilibrium fees in a subscription good market where all individuals have to purchase the good (like in education, health care, and pensions) and where firms charge a uniform price across customers. In the absence of policies that address inelastic demand, a government competitor may likely be ineffective, and costs could increase to low-income workers in particular if they are on average less price sensitive, as many firms respond to competitive entry by raising prices on their brand-captive consumer segments. In general, policies that address price insensitivity and the potentially persuasive impacts of advertising are effective at increasing competition and lowering equilibrium prices.

\section{Conclusion}

We used a new data set with rich detail on pension fund choices in Mexico's privatized social security system to examine how sales force can affect prices, competition, and efficiency in a private pension market. The Mexican system's inception period gives us a unique opportunity to examine the role that sales force advertising can play in a highly important and policy-relevant market. Fund management firms in the system set market-wide prices, but chose sales force locally. Using measures of sales force exposure, we develop and estimate a very flexible model of demand for fund managers (Afores) and find that Afores' agent-based sales

forces were a key competitive channel used to gain customers at high fees by simultaneously increasing brand value and decreasing price sensitivity.

The system's regulators at the time made an explicit decision to follow a hands-off approach regarding information provision. The expectation was that reasonably unconcentrated market would result in pricedriven competition for fully-informed clients. We find instead that competition with advertising instead led to lower price sensitivities, especially among lower-wage workers. Rather than serving to inform workers about the effective prices of the options available to them, advertising served to weaken price sensitivity and instead shift choices to attributes tied to brand or other aspects of the product (real or psychological). As a result, prices were at levels well above marginal cost.

We explored whether two hypothetical policies would foster greater price competition. One focused on the supply side of the market by having the existing government-co-branded fund manager act as a low-cost 
public option. The other was a demand-side policy that increased workers' sensitivity to price differences across account managers. Perhaps surprisingly, the supply-side intervention had little impact on average fees in isolation, and in fact served to raise fees for many workers. The reason is that there are enough inelastic workers in the market to cause firms to respond to the low-cost producer by raising fees and focusing on the price-insensitive segment of the market. On the other hand, a demand-side policy that increases workers' price elasticity of demand would lead to a considerable decrease in fees, as more elastic consumers raise firms' incentives to compete on a price basis. The greatest impact on fees occurs when we combine these policies. They are complements because when consumers are more price-sensitive, there is no longer an incentive for firms to respond to a government competitor by raising prices to sell to inelastic customer segments.

Our analysis demonstrates that, even in a market with a large number of firms and financially homogeneous products, price competition need not be intense in the face of sales-force-driven differentiation. Given that this market, the Mexican social security retirement system, is an example of the privatization of pension systems that have been proposed in many countries, there are important policy implications of our findings. The results here indicate that, to the extent policymakers care about the total costs paid to operate a privatized system, it may be necessary to do more than simply set up a market with several players and free information flows. If firms can increase search costs, decrease price comparability, or engage in persuasive advertising, they can decrease price sensitivity and increase margins (Gabaix and Laibson 2006; Carlin 2009; Ellison and Ellison 2009; Carlin and Manso 2011; Ellison and Wolitsky 2012; Grubb 2015a,b). Our results show that the structures of preferences and advertising technologies in the Mexican market allowed them to channel competitive efforts into brand-oriented advertising that served to make workers less price sensitive. At the same time, our findings suggest that merely creating a low-cost public option will not necessarily foster price competition. Instead, demand-side efforts that raise workers' sensitivity to the costs they pay for management of their accounts are the most fruitful interventions. Our results may also hold broader lessons about the nature of competition in consumer financial markets more generally, when actual costs can be difficult for consumers to calculate and both brands and branding efforts are salient. 


\section{$\underline{\text { References }}$}

Abaluck, Jason and Jonathan Gruber. "Choice Inconsistencies among the Elderly: Evidence from Plan Choice in the Medicare Part D Program,” American Economic Review, 101(4), 2011, 1180-1210.

Ad Age Data Center. "Financial Services Marketing." October $8^{\text {th }}, 2012$. Accessed on June 19, 2016 : http://gaia.adage.com/images/bin/pdf/AdAgeFinancial\%20ServicesReport2012.pdf.

Altonji, Joseph G., Todd E. Elder, and Christopher R. Taber, "Selection on Observed and Unobserved Variables: Assessing the Effectiveness of Catholic Schools,” Journal of Political Economy, 113(1), 2005, 151-184.

Ashraf, Nava, Dean Karlan and Welsey Yin. 2006. "Tying Odysseus to the Mast: Evidence From a Commitment Savings Product in the Phillipines.” The Quarterly Journal of Economics, 121(2): 635672.

Ashraf, Nava, James Berry, and Jesse Shapiro. 2010. "Can Higher Prices Stimulate Product Use? Evidence from a Field Experiment in Zambia.” American Economic Review, 100(5): 2382-2413.

Ausubel, Lawrence M., "The Failure of Competition in the Credit Card Market," American Economic Review, 81(1), 1991, 50-81.

Ausubel, Lawrence M., “Adverse Selection in the Credit Card Market,” Working Paper, University of Maryland, 1999.Berndt, Ernst R., Margaret Kyle, and Davina Ling, “The Long Shadow of Patent Expiration: Generic Entry and Rx-to-OTC Switches,” in Scanner data and price indexes, Chicago IL: University of Chicago Press, 2003.

Berry, Steven T., "Estimating Discrete-Choice Models of Product Differentiation,” RAND Journal of Economics, 23(2), 1994, 242-262.

Bertrand, Marianne,Dean Karlan, Sendhill Mullainathan, Eldar Shafir, and Jonathan Zinman, "What’s Advertising Content Worth? Evidence from a Consumer Credit Marketing Field Experiment,” The Quarterly Journal of Economics, 125(1), 2010, 263-306.

Borghans, Lex, Angela Duckworth, James T. Heckman, and Bas ter Weel, "The Economics and Psychology of Personality Traits,” Journal of Human Resources, 43(4), 2008.

Butters, Gerard R., "Equilibrium Distributions of Sales and Advertising Prices," Review of Economic Studies, 44(3), 1977, 465-91.

Carlin, Bruce. 2009. "Strategic price complexity in retail financial markets.” Journal of Financial Economics, 91: 278-287.

Carlin, Bruce and Gustavo Manso. 2011. “Obfuscation, Learning, and the Evolution of Investor Sophistication.” Review of Financial Studies, 24: 754-785.

Ching, A., T. Erdem, and M.P. Keene. 2009. “The price consideration model of brand choice.” Journal of Applied Econometrics, 24: 393-420.

Choi, James J., David Laibson, Brigitte C. Madrian, and Andrew Metrick, "Reinforcement Learning and Savings Behavior.” Journal of Finance, 64(6), 2009, 2515-2533.

Choi, James J., David Laibson, and Brigitte C. Madrian, "Why Does the Law of One Price Fail? An Experiment on Index Mutual Funds,” Review of Financial Studies, 23(4), 2010, 1405-1432.

Christofferson, S. and D. Musto. 2002. "Demand curves and the pricing of money management." Review of Financial Studies, 15: 1499-1524.

Cronqvist, Henrik. “Advertising and Portfolio Choice.”CeRP Working Paper 44, 2006.

Davis, Steven J., Kevin M. Murphy, and Robert H. Topel, "Entry, Pricing, and Product Design in an Initially Monopolized Market,” Journal of Political Economy, 112(S1), 2004, S188-S225.

De los Santos, Babur, Ali Hortaçsu, and Matthijs Wildenbeest, “Testing models of consumer search using data on web browsing and purchasing behavior," American Economic Review, 102(6), 2012, 2955-80.

Duarte, Fabian and Justine Hastings, "Fettered Consumers and Sophisticated Firms: Evidence from Mexico's Privatized Social Security Market,” NBER Working Paper 18582, 2012.

Egan, Mark, "Brokers vs. Retail Investors: Conflicting Interests and Dominated Products.” Unpublished manuscript, University of Chicago, 2015. 
Einav, Liran, Amy Finkelstein, Stephen P. Ryan, Paul Schrimpf, and Mark R. Cullen, "Selection on Moral Hazard in Health Insurance,” American Economic Review, 103(1), 2013, 178-219.

Ellison, Glenn and Sara Fisher Ellison. 2009. "Search, Obfuscation, and Price Elasticities on the Internet." Econometrica, 77(2): 427-452.

Ellison, Glenn and Alexander Wolitzky. 2012. “A Search Cost Model of Obfuscation.” Rand Journal of Economics, 43(3): 417-441.

Fehr, Ernst and Lorenz Goette. 2007. "Do Workers Work More if Wages are High? Evidence from a Randomized Field Experiment.” American Economic Review, 97(1): 298-317.

Frank, Richard G., and David S. Salkever, "Generic Entry and the Pricing of Pharmaceuticals," Journal of Economics and Management Strategy, 6(1), 1997, 75-90.

Frank, Richard and David Salkever. 1992. "Pricing Patent Loss and the Market for Pharmaceuticals.” Southern Economic Journal, 59(2): 165-179.

Gabaix, Xavier, and David Laibson, "Shrouded Attributes, Consumer Myopia, and Information Suppression in Competitive Markets,” Quarterly Journal of Economics, 121(2), 2006, 505-40.

Glazer, Amihai and Henry McMillan, "Pricing by the Firm Under Regulatory Threat," Quarterly Journal of Economics, 107(3), 1992, 1089-1099.

Goeree, Michelle Sovinsky, "Limited Information and Advertising in the U.S. Personal Computer Industry, Econometrica, 76(5), 2008, 1017-74.

Grubb, Michael D. and Matthew Osborne, “Cellular Service Demand: Biased Beliefs, Learning, and Bill Shock”. Unpublished Manuscript, Massachusetts Institute of Technology , 2012.

Grubb, Michael. 2015a. “Overconfident Consumers in the Marketplace.” Journal of Economic Perspectives (under revision).

Grubb, Michael. 2015b. “Failing to Choose the Best Price: Theory, Evidence, and Policy.” Review of Industrial Organization (forthcoming).

Gurun, Umit, Gregor Matvos, and Amit Seru. 2015. “Advertising Expensive Mortgages.” Journal of Finance (forthcoming).

Hall, Robert E. and Susan Woodward, "Diagnosing Consumer Confusion and Sub-Optimal Shopping Effort: Theory and Mortgage-Market Evidence,” American Economic Review, 102(7), 2012, 3249-3276.

Handel, Benjamin, “Adverse Selection and Inertia in Health Insurance Markets: When Nudge Hurts,” NBER Working Paper 17459, 2012.

Hastings, Justine S. and Lydia Tejada-Ashton, "Financial Literacy, Information, and Demand Elasticity: Survey and Experimental Evidence from Mexico.” NBER Working Paper 14538, 2008.

Hastings, Justine S. and Olivia S. Mitchell. "How Financial Literacy and Impatience Shape Retirement Wealth and Investment Behaviors.” NBER Working Paper 16740, 2011.

Hastings, Justine S., Brigitte C. Madrian, and Bill Skimmyhorn, "Financial Literacy, Financial Education and Economic Outcomes,” Annual Review of Economics, 5(1) , 2013, 347-373.

Hastings, Justine S., Thomas Kane, and Douglas Staiger, "Heterogeneous Preferences and the Efficiency of Public School Choice,” NBER Working Papers 12145 and 11805, 2010

Hastings, Justine S. and Lindsey M. Wilson. 2017. "Impatience, Information and Investment Choice: Field Experimental Evidence in Mexico’s Privatized Social Security System.” Unpublished Manuscript, Brown University.

Hastings, Justine S., Christopher Neilson, Anely Ramirez, and Seth Zimmerman. 2015a. “(Un)informed College Choice: Evidence from Linked Survey and Administrative Data.” Economics of Education Review (forthcoming).

Hastings, Justine S., Christopher Neilson, and Seth Zimmerman. 2015b. "The Effects of Earnings Disclosure on College Enrollment Decisions,” NBER Working Paper 21300.

Heiss, Florian, Daniel McFadden, and Joachim Winter, "Mind the Gap! Consumer Perceptions and Choices of Medicare Part D Prescription Drug Plans," in Research Findings in the Economics of Aging, David A. Wise, ed., Chicago, IL: University of Chicago Press, National Bureau of Economic Research, 2010.

Honka, Elisabeth, Ali Hortaçsu, and Maria Ana Vitorino, “Advertising, Consumer Awareness and Choice: Evidence from the U.S. Banking Industry,” Working paper, University of Chicago, 2016. 
Hortaçsu, Ali and Chad Syverson, "Product Differentiation, Search Costs, and Competition in the Mutual Fund Industry: A Case Study of S\&P 500 Index Funds,” Quarterly Journal of Economics, 119(2), 2004, 403-456.

Hyslop, Dean R. and Guido W. Imbens, "Bias from Classical and Other Forms of Measurement Error," Journal of Business and Economic Statistics, 19(4), 2001, 475-481.

Jensen, Robert. 2010. “The (Perceived) Returns to Education and the Demand for Schooling.” The Quarterly Journal of Economics, 125(2): 515-548.

Jiang, Lia, “The Welfare Effects of "Bill Shock” Regulation in Mobile Telecommunication Markets,” Unpublished manuscript, 2012.

Karlan, Dean. 2005. "Using Experimental Economics to Measure Social Capital and Predict Financial Decisions.” American Economic Review, 95(5): 1688-1699.

Loewenstein, G., C. Sunstein, and R. Golman. 2014. "Disclosure: Psychology changes everything.” Annual Review of Economics, 6: 391-419.

Mehta, N., S. Rajiv, and K. Srinivasan. 2003. "Price uncertainty and consumer search: a structural model of consideration set formation.” Marketing Science, 22(1): 58-84.

Miravete, Eugenio J., "Choosing the Wrong Calling Plan? Ignorance and Learning,” American Economic Review, 93, 2003, 297-310.

Mullainathan, Sendhil, Jeffrey R Kling, Eldar Shafir, Lee Vermeulen, and Marian V Wrobel. 2012. "Comparison Friction: Experimental Evidence from Medicare Drug Plans.” Quarterly Journal of Economics 127 (1): 199-235.

Mullainathan, Sendhil, Markus Noeth, and Antoinette Schoar. 2012. "The Market for Financial Advice: An Audit Study,” NBER Working Paper 17929, 2012.

Ponce-Rodriguez Alejandro. "Teaser Rate Offers in the Credit Card Market: Evidence from Mexico.” PhD diss., Stanford Univ. 2008.

Stango, Victor, "Strategic Responses to Regulatory Threat in the Credit Card Market," Journal of Law and Economics, 46(2), 2003, 427-452.

Sun, Yang, “The Effect of Index Fund Competition on Money Management Fees.” (April 15, 2014). Available at SSRN: http://ssrn.com/abstract=2432361 or http://dx.doi.org/10.2139/ssrn.2432361

Surri, Erik and Peter Tufano. 1998. "Costly Search and Mutual Fund Flows.” The Journal of Finance, 53(5): 1589-1622.

Train, Ken. 2013. Discrete Choice Methods with Simulation. Cambridge University Press.

van Nierop, E., R. Bronnenberg, R. Paap, M. Wedel, and P.H. Franses. 2010. "Retrieving unobserved consideration sets from household panel data." Journal of Marketing Research, 47: 63-74.

Waldfogel, Joel, “The Tyranny of the Market,” Cambridge, MA: Harvard University Press, 2007. 
FIGURE I: DISTRIBUTION OF SALES FORCE ACROSS AFORES AND OVER TIME

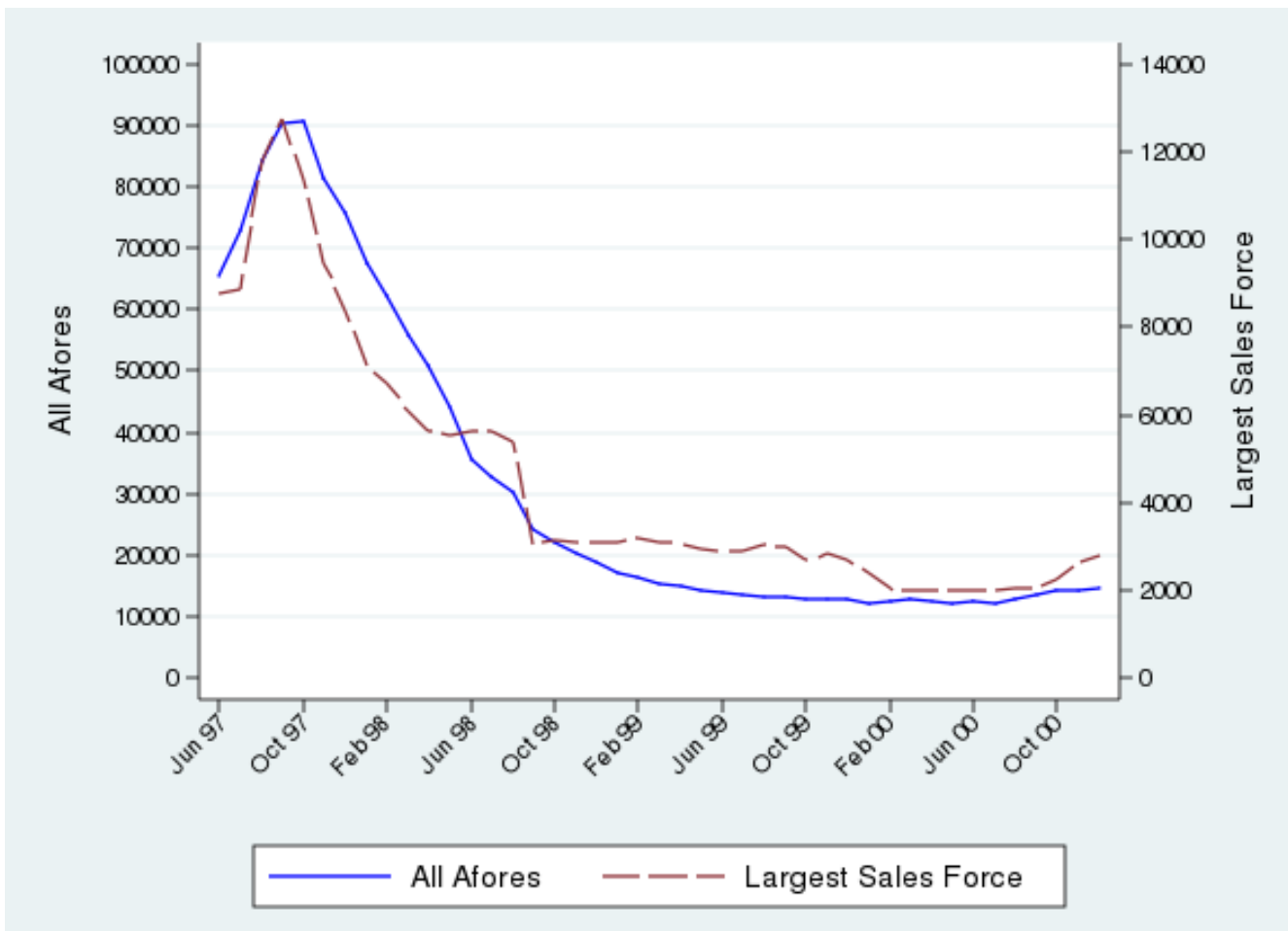

Note: Data from official Sales Agent Registration panel from CONSAR. Data record each sales agent, their current status, and the Afore for whom they are working. "All Afores" series plots the total sales force across all Afores. "Largest Sales Force" series plots the maximum sales force in each year and month across all Afores. 
FIGURE II: MEAN AND MEDIAN AFORE FEES OVER TIME

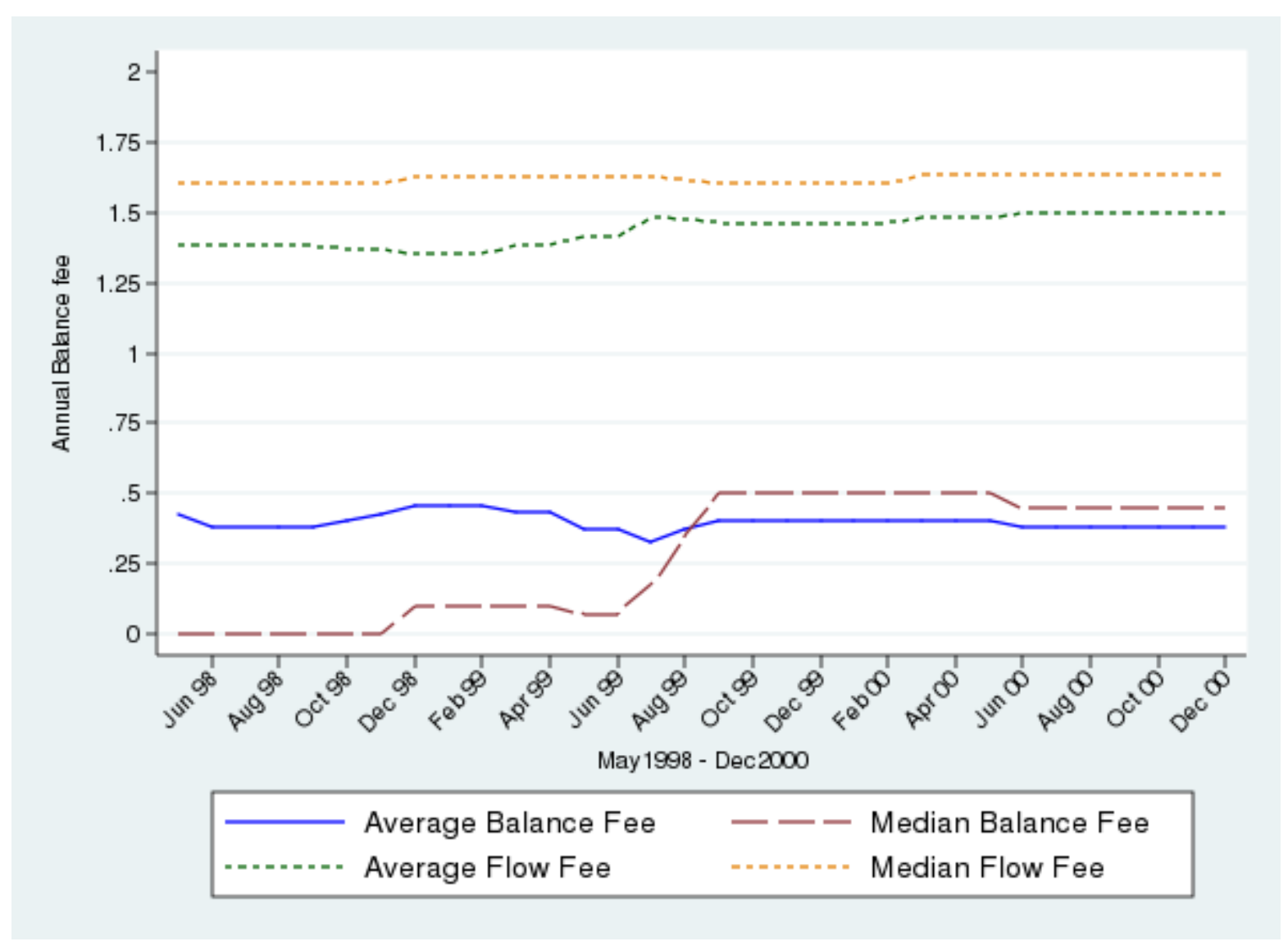

Notes: Average and median flow and balance fees are reported across all Afores in the market in each month and year.

Flow fees for Afores reported as a percentage of salary from May 1998 to December 2000. Balance fees are reported in percentages. A value of .5 is $0.5 \%$. 
FIGURE III:

MARK-UP, SALES FORCE AND MARKET SHARE

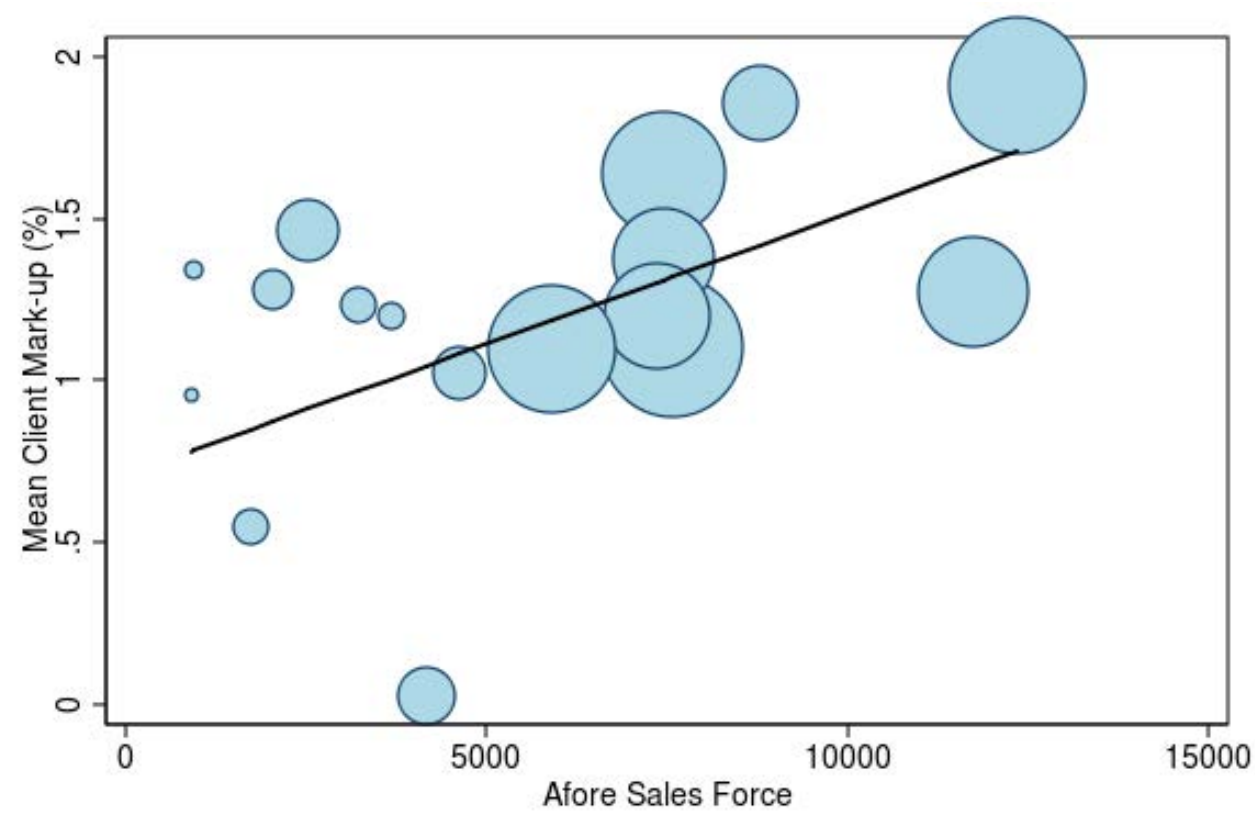

- Mean Mark-up for Own Clients — Linear Regression Prediction

Notes: Mean Client Mark-up plots the average percentage mark-up in total costs relative to the cheapest Afore option for clients in each Afore. A mark-up of 1 indicates the total projected costs for an Afore's clients is on average twice as large as what they would be expected to pay in the cheapest option for them. Markers are weighted by market shares of accounts, as defined in Table I, with larger markers indicating larger market shares. Projected costs over 10 years were calculated for each worker using their actual contributions, initial balance and wages recorded in the administrative data from 1997-2007, assuming that Afore fees were held constant going forward. Expected costs for each worker were then calculated by averaging projected costs in each year over workers with similar baseline characteristics. Linear Regression Prediction is the fitted line from a regression of Mean Client Mark-up on Afore Sales Force, weighted by market share. 
FIGURE IV:

SALES FORCE AND THE RELATIONSHIP BETWEEN PRICE AND MARKET SHARE

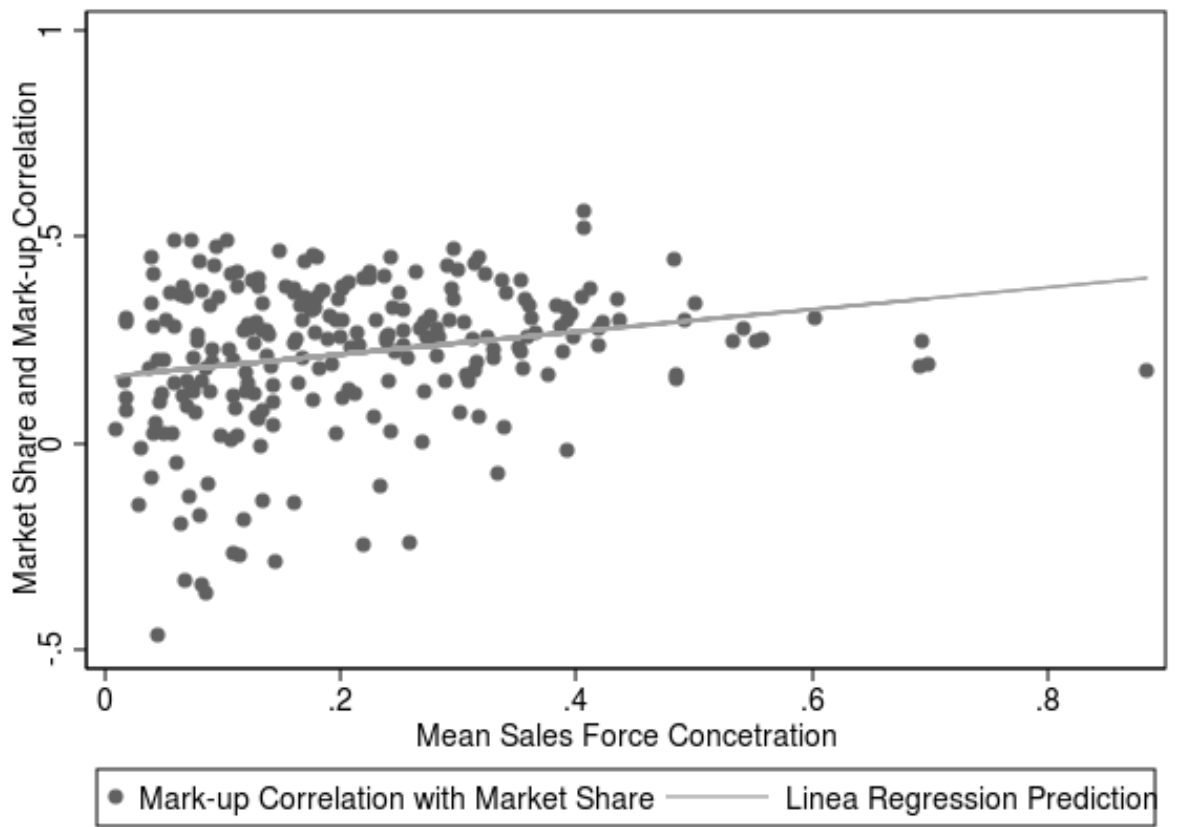

Notes: Mark-up Correlation with Market Share is calculated in the following way. For each municipality, we calculate the correlation between the mean mark-up each Afore's clients pay over their lowest cost option and Afore market share. Municipality mark-up and market share correlations are regressed on municipality mean wages and fraction male. This figure plots those residuals (plus the overall mean) versus mean sales force concentration. Mean sales force concentration is the average number of sales force per 1000 potential clients across Afores within each municipality. Linear Regression Prediction is the fitted line from a regression of the regression-adjusted market share and mark-up correlation on Afore Sales Force. 
FIGURE V:

MEAN ELASTICITY: BASELINE vs. NEUTRAL AGENTS

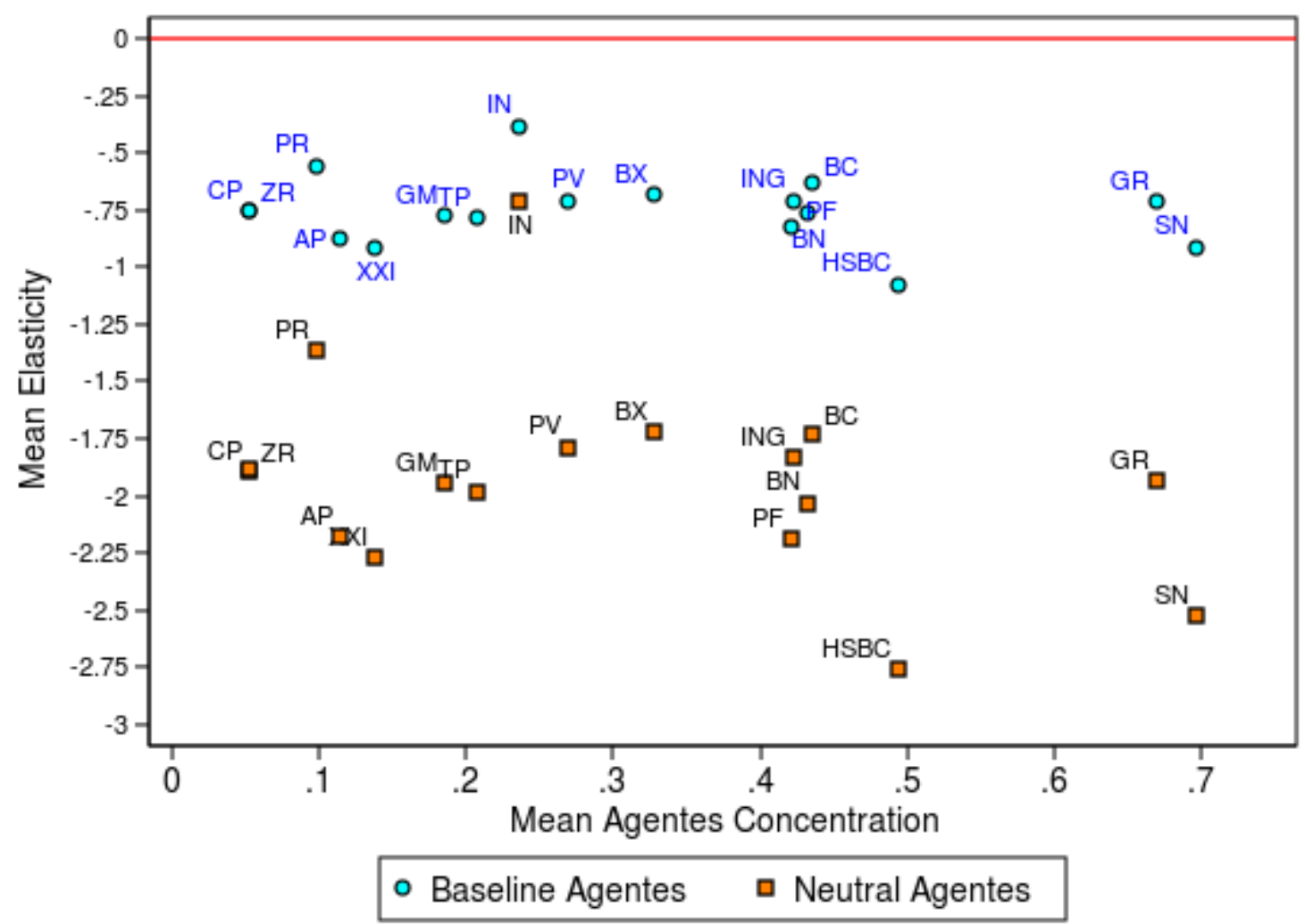

\begin{tabular}{|lll|}
\hline \multicolumn{2}{c}{ Afore Legend: } & \\
AP-Atlantico Promex & GR-Garante & PV-Previnter \\
BC-Bancomer & HSBC-Bancrecer/Dresdner/HSBC & SN-Santander \\
BN-Banorte Generali & IN-Inbursa & TP-Tepeyac \\
BX-Banamex & ING-ING / Bital & XXI-XXI \\
CP-Capitaliza & PF-Profuturo GNP & ZR-Zurich \\
GM-Genesis Metropolitan & PR-Principal & \\
\hline
\end{tabular}

Note: Elasticities are calculated at the observed fee levels and individual characteristics. Elasticities in the Baseline Agents model are calculated using estimates from equation 2 to generate the logit choice probability for each individual for each Afore. Elasticities for the Neutral Agents model use estimates for demand parameters with Neutral Agents from equations 4, 5 and 6 using the instrumental variables results from Table III column 4 and Table V column 1. 
TABLE I: DESCRIPTIVE STATISTICS OF AFORES AT THE INCEPTION OF MARKET

\begin{tabular}{|c|c|c|c|c|c|}
\hline Afore & Flow fee & $\begin{array}{c}\text { Implied } \\
\text { Load on } \\
\text { Contributions } \\
\end{array}$ & Balance fee & $\begin{array}{c}\text { Share of } \\
\text { Accounts }\end{array}$ & $\begin{array}{c}\text { Number of } \\
\text { Agents }\end{array}$ \\
\hline Santander & $1.70 \%$ & $26.15 \%$ & $1.00 \%$ & $14.60 \%$ & 12,361 \\
\hline Garante & $1.68 \%$ & $25.85 \%$ & $0.00 \%$ & $9.83 \%$ & 11,756 \\
\hline $\begin{array}{l}\text { Bancrecer/ } \\
\text { Dresdner/HSBC }\end{array}$ & $0.00 \%$ & $0.00 \%$ & $4.75 \%$ & $4.62 \%$ & 8,804 \\
\hline Bancomer & $1.70 \%$ & $26.15 \%$ & $0.00 \%$ & $16.12 \%$ & 7,583 \\
\hline Profuturo GNP & $1.70 \%$ & $26.15 \%$ & $0.50 \%$ & $12.45 \%$ & 7,443 \\
\hline Banorte Generali & $1.00 \%$ & $15.38 \%$ & $1.50 \%$ & $8.35 \%$ & 7,440 \\
\hline ING / Bital & $1.68 \%$ & $25.85 \%$ & $0.00 \%$ & $9.21 \%$ & 7,369 \\
\hline Banamex & $1.70 \%$ & $26.15 \%$ & $0.00 \%$ & $12.94 \%$ & 5,914 \\
\hline Previnter & $1.55 \%$ & $23.85 \%$ & $0.00 \%$ & $2.28 \%$ & 4,614 \\
\hline Inbursa & $0.00 \%$ & $0.00 \%$ & $1.57 \%$ & $2.52 \%$ & 4,150 \\
\hline Тереуас & $1.17 \%$ & $18.00 \%$ & $1.00 \%$ & $0.52 \%$ & 3,685 \\
\hline Genesis Metropolitan & $1.65 \%$ & $25.38 \%$ & $0.00 \%$ & $0.94 \%$ & 3,213 \\
\hline XXI & $1.50 \%$ & $23.08 \%$ & $0.99 \%$ & $2.88 \%$ & 2,521 \\
\hline Atlantico Promex & $1.40 \%$ & $21.54 \%$ & $0.95 \%$ & $1.32 \%$ & 2,045 \\
\hline Principal & $0.90 \%$ & $13.85 \%$ & $1.00 \%$ & $1.01 \%$ & 1,732 \\
\hline Capitaliza & $1.60 \%$ & $24.62 \%$ & $0.00 \%$ & $0.23 \%$ & 925 \\
\hline Zurich & $0.95 \%$ & $14.62 \%$ & $1.25 \%$ & $0.18 \%$ & 910 \\
\hline
\end{tabular}

Note: Implied Load on Contributions is the Flow Fee divided by 6.5\% (the share of salary automatically placed in the SAR account). Share of accounts is calculated using all account holders as of June 2006 who entered the SAR 1997 system before June 1998. Santander is a Spanish financial group. Garante is a Mexican insurance and financial group. Bancrecer/Dresdner/HSBC is an international financial group. Bancomer is the second largest Mexican bank. Profuturo GNP is a Mexican insurance group. Banorte Generali is a joint venture between a large northern Mexican bank, Banorte, and the largest Italian insurance company, Assicurazioni Generali S.p.A. ING/Bital is an international financial group. Banamex is the largest Mexican bank. Previnter is a France-based international insurance company, acquired by Profuturo GNP in late 1998. Inbursa is the financial arm of Telcel magnate's Slim Corporation. Tepeyac is a Mexican insurance company. Genesis Metropolitan is owned by the US-based insurance company, Metropolitan Life. It was acquired by Santander in late 1998. XXI is the Afore branded by IMSS, the former pension system administrator. Atlantico Promex is a Mexican financial group which was acquired by Principal in late 1998. Principal is an international financial group. Capitaliza is a Mexican financial group and was acquired by Inbursa in late 1998. Zurich is an international commercial insurance company. 
TABLE II: DESCRIPTIVE STATISTICS OF MANAGEMENT COSTS, MARKET SHARES, SALES FORCE AND PRICE SENSITIVITY, BY AFORE

\begin{tabular}{|c|c|c|c|c|c|c|c|c|}
\hline & $\begin{array}{l}\text { Number } \\
\text { of } \\
\text { Agents }\end{array}$ & $\begin{array}{c}\text { Share of } \\
\text { Account } \\
\text { s }\end{array}$ & $\begin{array}{l}\text { Mean } \\
\text { Rank for } \\
\text { Own } \\
\text { Clients }\end{array}$ & $\begin{array}{l}\text { Mean } \\
\text { Rank in } \\
\text { the } \\
\text { System }\end{array}$ & $\begin{array}{l}\text { Markup } \\
\text { Over } \\
\text { Cheapest } \\
\text { Option }\end{array}$ & $\begin{array}{c}\text { Mean } \\
\text { Savings } \\
\text { in Days } \\
\text { of } \\
\text { Wages }\end{array}$ & $\begin{array}{c}\text { Mean } \\
\text { Daily } \\
\text { Wage of } \\
\text { Clients } \\
\text { (1997 } \\
\text { Pesos) } \\
\end{array}$ & $\begin{array}{c}\text { Fraction } \\
\text { of } \\
\text { Clients } \\
\text { who are } \\
\text { Male }\end{array}$ \\
\hline Santander & 12,361 & $14.6 \%$ & 16.5 & 16.5 & 1.9 & 42.5 & 61.2 & 0.72 \\
\hline Garante & 11,756 & $9.8 \%$ & 11.1 & 11.0 & 1.3 & 30.7 & 75.9 & 0.69 \\
\hline $\begin{array}{l}\text { Bancrecer/Dresdner/H } \\
\text { SBC }\end{array}$ & 8,804 & $4.6 \%$ & 14.2 & 14.1 & 1.9 & 55.7 & 69.9 & 0.69 \\
\hline Bancomer & 7,583 & $16.1 \%$ & 7.4 & 7.6 & 1.1 & 29.4 & 109.6 & 0.67 \\
\hline Profuturo GNP & 7,443 & $12.5 \%$ & 14.4 & 14.4 & 1.6 & 34.6 & 59.1 & 0.71 \\
\hline Banorte Generali & 7,440 & $8.4 \%$ & 8.0 & 9.2 & 1.4 & 34.0 & 64.3 & 0.68 \\
\hline ING / Bital & 7,369 & $9.2 \%$ & 8.1 & 8.0 & 1.2 & 29.0 & 74.7 & 0.64 \\
\hline Banamex & 5,914 & $12.9 \%$ & 9.7 & 10.0 & 1.1 & 28.4 & 97.8 & 0.67 \\
\hline Previnter & 4,614 & $2.3 \%$ & 4.1 & 4.2 & 1.0 & 24.9 & 96.1 & 0.65 \\
\hline Inbursa & 4,150 & $2.5 \%$ & 1.2 & 1.3 & 0.0 & 0.5 & 218.6 & 0.65 \\
\hline Тереуас & 3,685 & $0.5 \%$ & 7.2 & 7.6 & 1.2 & 27.1 & 70.1 & 0.71 \\
\hline Genesis Metropolitan & 3,213 & $0.9 \%$ & 8.1 & 7.9 & 1.2 & 25.9 & 63.1 & 0.64 \\
\hline XXI & 2,521 & $2.9 \%$ & 14.8 & 14.8 & 1.5 & 39.3 & 120.7 & 0.57 \\
\hline Atlantico Promex & 2,045 & $1.3 \%$ & 13.0 & 12.9 & 1.3 & 38.5 & 74.6 & 0.66 \\
\hline Principal & 1,732 & $1.0 \%$ & 2.4 & 2.3 & 0.6 & 11.4 & 76.7 & 0.67 \\
\hline Capitaliza & 925 & $0.2 \%$ & 6.1 & 5.5 & 1.3 & 23.1 & 99.4 & 0.67 \\
\hline Zurich & 910 & $0.2 \%$ & 5.9 & 5.5 & 1.0 & 26.6 & 96.8 & 0.83 \\
\hline $\begin{array}{l}\text { Correlation with } \\
\text { Num. Sales Agents }\end{array}$ & 1.00 & 0.79 & 0.50 & 0.52 & 0.48 & 0.45 & -0.28 & 0.06 \\
\hline
\end{tabular}

Notes: Afore rank is based on expected costs, and runs from 1 to 17 where a 1 indicates the lowest cost. Mean Rank of Own Clients is the average expected cost rank of that Afore among the Afore's clients. Mean Rank in the System s is the average expected cost rank for that Afore over all clients in the system. For each worker, expected costs are calculated by averaging projected costs, calculated using actual contributions, initial balance and wages over a 10 year period, in each year over workers with similar baseline characteristics. The Online Appendix provides details on the expected cost estimation. Mark up over Cheapest Option is calculated for each person as the expected cost at each Afore minus the expected cost at the cheapest Afore for them, divided by the cost of the cheapest Afore for them. This is then averaged over all clients in each Afore. Savings in days of wages is the number of days' wages that a worker could save if she/he switched from their current Afore to the Afore with the lowest expected cost. 
TABLE III: IMPACT OF SALES FORCE ON AFORE BRAND VALUE

\begin{tabular}{|c|c|c|c|c|}
\hline & (1) & $(2)$ & (3) & (4) \\
\hline Dependent Variable: $\delta_{c, j}$ & OLS & IV 1 & IV 2 & IV 3 \\
\hline $\begin{array}{l}\text { Municipality sales force } \\
\text { concentration for Afore } j\end{array}$ & $\begin{array}{c}2.793 * * * \\
(0.136)\end{array}$ & $\begin{array}{c}4.499 * * * \\
(0.031)\end{array}$ & $\begin{array}{c}4.404 * * * \\
(0.031)\end{array}$ & $\begin{array}{c}4.169 * * * \\
(0.029)\end{array}$ \\
\hline $\begin{array}{l}\text { Municipality concentration of bank } \\
\text { branches for Afore } j\end{array}$ & $\begin{array}{l}28.311^{* * *} \\
(2.431)\end{array}$ & $\begin{array}{l}21.582 * * * \\
(0.661)\end{array}$ & $\begin{array}{l}21.957 * * * \\
(0.657)\end{array}$ & $\begin{array}{l}22.884 * * * \\
(0.647)\end{array}$ \\
\hline $\begin{array}{l}\text { Indicator if Afore } j \text { is affiliated with } \\
\text { a bank. }\end{array}$ & $\begin{array}{c}0.715^{* * *} \\
(0.055)\end{array}$ & $\begin{array}{c}0.483 * * * \\
(0.014)\end{array}$ & $\begin{array}{c}0.496 * * * \\
(0.013)\end{array}$ & $\begin{array}{c}0.528 * * * \\
(0.013)\end{array}$ \\
\hline Observations & 62,883 & 62,883 & 62,883 & 62,883 \\
\hline Mean $\delta_{c, j}$ & -2.743 & & & \\
\hline Mean Salesforce & 0.280 & & & \\
\hline StDev Salesforce & 0.312 & & & \\
\hline Mean Branches & 0.004 & & & \\
\hline StDev Branches & 0.010 & & & \\
\hline F-Stat for Excluded Instruments & -- & 1425.70 & 1038.04 & 728.24 \\
\hline Number of cells & 3,699 & 3,699 & 3,699 & 3,699 \\
\hline \multicolumn{5}{|c|}{$\begin{array}{l}\text { Robust standard errors in parentheses. } * * * \mathrm{p}<0.01, * * \mathrm{p}<0.05, * \mathrm{p}<0.1 \text {. The dependent variable is the } \\
\text { estimated mean valuation of Afore } j \text { for system affiliates in demographic and municipality cell } c \text { estimated } \\
\text { using equation (3) in the text. It measures mean value relative to the excluded Afore, whose identity is held } \\
\text { constant across all municipalities. All specifications include cell-level fixed effects and an indicator if the } \\
\text { Afore had zero market share in that cell. Municipality sales force concentration for Afore } j \text { is defined as the } \\
\text { number of agents for Afore } j \text { in municipality } m \text { divided by the total number of SAR affiliates in } m \text {. } \\
\text { Municipality concentration of bank branches for Afore } j \text { is defined as the number of bank branches in } \\
\text { municipality } m \text { divided by adult population in the municipality. Column } 1 \text { presents OLS estimates with } \\
\text { standard errors clustered at the municipality-Afore level. Column } 2 \text { presents instrumental variables } \\
\text { estimates using the advertising spillovers instrument (mean costs in same-municipality-other-demographic- } \\
\text { group cells for Afore jinteracted with Afore fixed effects). Column } 3 \text { adds competitor bank branches in the } \\
\text { municipality and its interaction with Afore fixed effects as instruments. Column } 4 \text { adds fraction of the } \\
\text { working-age cell population who are IMSS account holders and fraction of workers employed in the public } \\
\text { sector, both interacted with Afore fixed effects as additional instruments. }\end{array}$} \\
\hline
\end{tabular}


TABLE IV: EFFECT OF SALES AGENTS ON BRAND VALUE

\begin{tabular}{|c|c|c|c|c|c|c|c|}
\hline Dependent Variable: $\delta_{c, j}$ & Low Wage & $\begin{array}{c}\text { (2) } \\
\text { High Wage }\end{array}$ & $\begin{array}{c}(3) \\
\text { Male }\end{array}$ & $\begin{array}{c}\text { (4) } \\
\text { Female }\end{array}$ & $\begin{array}{l}(5) \\
\text { Younger }\end{array}$ & $\begin{array}{c}(6) \\
\text { Older }\end{array}$ & $\begin{array}{c}(7) \\
\text { Low Cost }\end{array}$ \\
\hline $\begin{array}{l}\text { Municipality sales force } \\
\text { concentration for Afore } j\end{array}$ & $\begin{array}{c}4.598 * * * \\
(0.040)\end{array}$ & $\begin{array}{l}3.660 * * * \\
(0.041)\end{array}$ & $\begin{array}{c}4.650 * * * \\
(0.040)\end{array}$ & $\begin{array}{c}3.502 * * * \\
(0.041)\end{array}$ & $\begin{array}{c}4.412 * * * \\
(0.041)\end{array}$ & $\begin{array}{c}3.908 * * * \\
(0.040)\end{array}$ & $\begin{array}{c}4.498 * * * \\
(0.075)\end{array}$ \\
\hline $\begin{array}{l}\text { Municipality concentration } \\
\text { of bank branches for Afore } j\end{array}$ & $\begin{array}{l}16.244^{* * *} \\
(0.888)\end{array}$ & $\begin{array}{c}30.302 * * * \\
(0.938)\end{array}$ & $\begin{array}{c}20.920 * * * \\
(0.864)\end{array}$ & $\begin{array}{l}25.556 * * * \\
(0.972)\end{array}$ & $\begin{array}{l}21.553^{* * *} \\
(0.915)\end{array}$ & $\begin{array}{c}24.356 * * * \\
(0.912)\end{array}$ & $\begin{array}{c}34.921^{* * *} \\
(1.525)\end{array}$ \\
\hline $\begin{array}{l}\text { Indicator if Afore } j \text { is } \\
\text { affiliated with a bank. }\end{array}$ & $\begin{array}{c}0.396 * * * \\
(0.018)\end{array}$ & $\begin{array}{c}0.694^{* * *} \\
(0.019)\end{array}$ & $\begin{array}{c}0.507 * * * \\
(0.017)\end{array}$ & $\begin{array}{c}0.559 * * * \\
(0.021)\end{array}$ & $\begin{array}{c}0.558 * * * \\
(0.019)\end{array}$ & $\begin{array}{c}0.496 * * * \\
(0.019)\end{array}$ & $\begin{array}{c}0.302 * * * \\
(0.028)\end{array}$ \\
\hline $\begin{array}{l}\text { Observations } \\
\text { Number of cells } \\
\text { Mean } \delta_{c, j}\end{array}$ & $\begin{array}{c}34,289 \\
2,017 \\
-2.985\end{array}$ & $\begin{array}{c}28,594 \\
1,682 \\
-2.452\end{array}$ & $\begin{array}{c}39,610 \\
2,330 \\
-2.779\end{array}$ & $\begin{array}{c}23,273 \\
1,369 \\
-2.680\end{array}$ & $\begin{array}{c}32,385 \\
1,905 \\
-2.803\end{array}$ & $\begin{array}{c}30,498 \\
1,794 \\
-2.679\end{array}$ & $\begin{array}{c}14,796 \\
3,699 \\
-3.105\end{array}$ \\
\hline \multicolumn{8}{|c|}{$\begin{array}{l}\text { Note: Instrumental variables specification from Table III, column } 4 \text {, by subgroup. }{ }^{* * *} \mathrm{p}<0.01,{ }^{*} \mathrm{p}<0.05,{ }^{*} \mathrm{p}<0.1 \text {. Wage cuts are defined as below or } \\
\text { above the median wage. Younger and older are defined as younger or older than } 35 \text { years old. Low Cost is an indicator if Afore } j \text { is one of the cheapest } \\
\text { four Afores for individuals in demographic-group-municipality cell } c \text {. The dependent variable is the estimated mean valuation of Afore } j \text { for system } \\
\text { affiliates in demographic and municipality cell } c \text { estimated using equation (3) in the text. It measures mean value relative to the excluded Afore, whose } \\
\text { identity is held constant across all municipalities. All specifications include cell-level fixed effects and an indicator if the Afore had zero market share in } \\
\text { that cell. Municipality sales force concentration for Afore } j \text { is defined as the number of agents for Afore } j \text { in municipality } m \text { divided by the total number of } \\
\text { SAR affiliates in } m \text {. It has a mean of } 0.28 \text { with a standard deviation of } 0.312 \text {. Municipality concentration of bank branches for Afore } j \text { is defined as the } \\
\text { number of bank branches in municipality } m \text { divided by adult population in the municipality, and has a mean of } 0.004 \text { with a standard deviation of } 0.01 \text {. }\end{array}$} \\
\hline
\end{tabular}


TABLE V: EFFECT OF SALES AGENTS ON MEAN PRICE SENSITIVITY

\begin{tabular}{|c|c|c|c|c|c|c|c|c|}
\hline Dependent Variable: $\alpha_{c}$ & Pooled & $\begin{array}{c}(2) \\
\text { Pooled }\end{array}$ & $\begin{array}{c}\text { (3) } \\
\text { Low } \\
\text { Wage }\end{array}$ & $\begin{array}{c}(4) \\
\text { High } \\
\text { Wage }\end{array}$ & Male & Female & Younger & Older \\
\hline $\begin{array}{l}\text { Municipality sales force } \\
\text { concentration }\end{array}$ & $\begin{array}{c}0.046 * * * \\
(0.012)\end{array}$ & $\begin{array}{l}0.051^{* * *} \\
(0.017)\end{array}$ & $\begin{array}{c}0.060 * * * \\
(0.020)\end{array}$ & $\begin{array}{c}0.020 * * * \\
(0.007)\end{array}$ & $\begin{array}{l}0.057 * * * \\
(0.016)\end{array}$ & $\begin{array}{c}0.019 \\
(0.014)\end{array}$ & $\begin{array}{c}0.054 * * * \\
(0.015)\end{array}$ & $\begin{array}{c}0.035 * * * \\
(0.013)\end{array}$ \\
\hline $\begin{array}{l}\text { Sales force concentration for } \\
\text { four lowest-cost Afores }\end{array}$ & & $\begin{array}{l}-0.026 \\
(0.045)\end{array}$ & & & & & & \\
\hline Constant & $\begin{array}{l}-0.605^{* * *} \\
(0.081)\end{array}$ & $\begin{array}{c}-0.606^{* * *} \\
(0.081)\end{array}$ & $\begin{array}{l}-0.845^{* * *} \\
(0.134)\end{array}$ & $\begin{array}{l}-0.272 * * * \\
(0.045)\end{array}$ & $\begin{array}{c}-0.692 * * * \\
(0.103)\end{array}$ & $\begin{array}{c}-0.410^{* * *} \\
(0.099)\end{array}$ & $\begin{array}{c}-0.686^{* * *} \\
(0.100)\end{array}$ & $\begin{array}{c}-0.510^{* * *} \\
(0.085)\end{array}$ \\
\hline Observations & 3,699 & 3,699 & 2,017 & 1,682 & 2,330 & 1,369 & 1,905 & 1,794 \\
\hline Mean Dep. Var. & -0.388 & -0.388 & -0.568 & -0.173 & -0.435 & -0.308 & -0.431 & -0.343 \\
\hline
\end{tabular}


TABLE VI: SIMULATED CHANGE IN ELASTICITY AND TOTAL COST, BASE MODEL VS. NEUTRAL ADVERTISING, BY DEMOGRAPHIC GROUP

\begin{tabular}{|c|c|c|c|c|c|}
\hline \multirow[b]{2}{*}{$\begin{array}{l}\text { Demographic } \\
\text { Group }\end{array}$} & \multirow[b]{2}{*}{$\begin{array}{l}\text { Mean Elasticity } \\
\text { Base Model }\end{array}$} & \multirow[b]{2}{*}{ Neutral Advertising } & \multicolumn{3}{|c|}{ Neutral Advertising vs. Base Model } \\
\hline & & & $\begin{array}{l}\text { Percent Change in } \\
\text { Total Cost }\end{array}$ & $\begin{array}{l}\text { Average Savings } \\
\text { Pesos Per Capita } \\
\text { (1997 pesos) }\end{array}$ & $\begin{array}{c}\text { Minimum Pension } \\
\text { Equivalent Per } \\
\text { Capita } \\
\text { (years) }\end{array}$ \\
\hline All & -0.754 & -1.925 & $-17.2 \%$ & $\$ 47,896$ & 6.9 \\
\hline Low Wage & -0.621 & -0.997 & $-5.3 \%$ & $\$ 5,634$ & 0.8 \\
\hline High Wage & -0.876 & -2.779 & $-19.9 \%$ & $\$ 86,760$ & 12.5 \\
\hline Male & -0.797 & -2.018 & $-17.8 \%$ & $\$ 53,330$ & 7.7 \\
\hline Female & -0.664 & -1.728 & $-15.6 \%$ & $\$ 36,439$ & 5.2 \\
\hline Younger & -0.821 & -1.677 & $-14.0 \%$ & $\$ 30,631$ & 4.4 \\
\hline Older & -0.680 & -2.200 & $-19.5 \%$ & $\$ 66,994$ & 9.6 \\
\hline
\end{tabular}

Notes: Computed using model estimates from equations (3) through (6), and estimated impact of sales force from Table III, column 4, and Table V, column 1. Pesos are reported in 1997 pesos. Minimum pension equivalents represent the Average Savings in Pesos as years of minimum pension guarantee payments. These payments are 580 pesos per month and distributed to those who have less than a minimum threshold income in old age. 


\section{All}

Low-income

High-income

Young workers

Old workers

Male

Female

Simulated Outcomes from

Neutral Agents Preferences at

New Equilibrium Fees

\begin{tabular}{ccc}
\hline $\begin{array}{c}\text { Percent Change in } \\
\text { Total Cost }\end{array}$ & $\begin{array}{c}\text { Average Savings } \\
\text { Pesos Per Capita } \\
(1997 \text { pesos) }\end{array}$ & $\begin{array}{c}\text { Minimum Pension } \\
\text { Equivalent Per } \\
\text { Capita } \\
\text { (years) }\end{array}$ \\
\hline$-62.1 \%$ & $\$ 215,169$ & 30.9 \\
$-55.5 \%$ & $\$ 70,307$ & 10.1 \\
$-64.3 \%$ & $\$ 347,844$ & 50.0 \\
$-63.5 \%$ & $\$ 112,723$ & 16.2 \\
$-62.5 \%$ & $\$ 328,137$ & 47.1 \\
$-60.3 \%$ & $\$ 264,997$ & 38.1 \\
$-64.5 \%$ & $\$ 191,492$ & 27.5
\end{tabular}

Note: Equilibrium calculations are based on an 80,229 random sample plus a proportional random sample of new workers who entered the market over time, to capture growth forecasts in market size. Equilibrium fees are calculated from an iterated best response method using a 0.00025 grid for the base model while for the models with raised caps, equilibrium fees are calculated from an iterated best response method using a 0.0005 grid. See Online Appendix for details on iterated best response method. Cost is calculated over the

whole account horizon and discounted at a 5\% rate. Detailed changed in cost by demographics are calculated using the 80,229 random sample. Pesos are reported in 1997 pesos. Minimum pension equivalents represent the Average Savings in Pesos as years of minimum pension guarantee payments. These payments are 580 pesos per month and distributed to those who have less than a minimum threshold income in old age. 
TABLE VIII: SUMMARY OF SIMULATION RESULTS WITH DISCONTINUOUS RESPONSES TO GOVERNMENT COMPETITOR

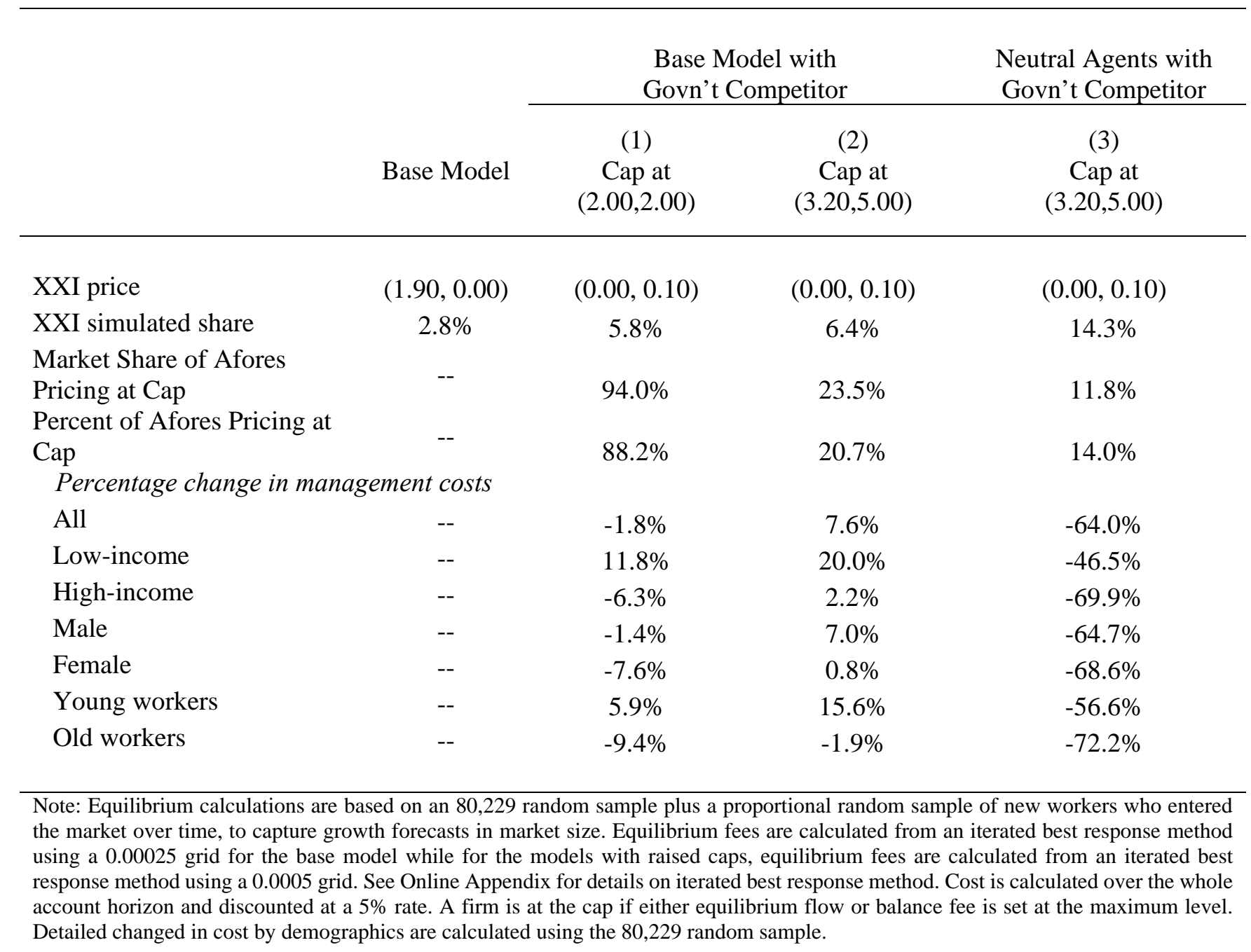




\begin{tabular}{|c|c|c|c|}
\hline & \multicolumn{3}{|c|}{ Policy Simulation } \\
\hline & $\begin{array}{c}\text { (1) } \\
\text { Increased demand } \\
\text { elasticity } \\
\text { for most inelastic }\end{array}$ & $\begin{array}{c}\text { (2) } \\
+ \text { Government } \\
\text { Competitor } \\
\end{array}$ & $\begin{array}{c}\text { (3) } \\
+ \text { Neutral Agents }\end{array}$ \\
\hline Market Share of Afores Pricing at Cap & $5.9 \%$ & $0.0 \%$ & $0.0 \%$ \\
\hline Percent of Afores Pricing at Cap & $10.3 \%$ & $0.0 \%$ & $0.0 \%$ \\
\hline \multicolumn{4}{|l|}{ Percentage change in management costs } \\
\hline All & $-33.9 \%$ & $-38.5 \%$ & $-73.5 \%$ \\
\hline Low-income & $-26.4 \%$ & $-22.1 \%$ & $-60.0 \%$ \\
\hline High-income & $-36.7 \%$ & $-44.5 \%$ & $-78.0 \%$ \\
\hline Young workers & $-30.7 \%$ & $-28.0 \%$ & $-67.5 \%$ \\
\hline Old workers & $-37.8 \%$ & $-49.5 \%$ & $-79.9 \%$ \\
\hline Male & $-34.4 \%$ & $-39.1 \%$ & $-74.1 \%$ \\
\hline Female & $-36.2 \%$ & $-44.6 \%$ & $-76.7 \%$ \\
\hline \multicolumn{4}{|c|}{$\begin{array}{l}\text { Note: Equilibrium calculations are based on an } 80,229 \text { random sample plus a proportional random sample of new workers who } \\
\text { entered the market over time, to capture growth forecasts in market size. Equilibrium fees are calculated from an iterated best } \\
\text { response method using a } 0.00025 \text { grid for the base model while for the models with raised caps, equilibrium fees are calculated } \\
\text { from an iterated best response method using a } 0.0005 \text { grid. See Online Appendix for details on iterated best response method. } \\
\text { Cost is calculated over the whole account horizon and discounted at a } 5 \% \text { rate. A firm is at the cap if either equilibrium flow or } \\
\text { balance fee is set at the maximum level. Share of firms at cap denotes the total predicted market share of the Afores at the cap. } \\
\text { Detailed changed in cost by demographics are calculated using the } 80,229 \text { random sample. }\end{array}$} \\
\hline
\end{tabular}

